\title{
High-Level Waste Glass Formulation Model Sensitivity Study 2009 Glass Formulation Model versus 1996 Glass Formulation Model
}

\author{
JD Belsher, FL Meinert \\ Washington River Prolection Solutionts \\ Richland, WA 99352 \\ U S Department of Energy ContraciDE-AC27-08RV14800

$\begin{array}{llll}\text { EDT/ECN } & \text { DRF } & \text { UC N/A } & \\ \text { Cost Center } & \text { N/A } & \text { Charge Code } & \text { N/A } \\ \text { BSR Code } & \text { N/A } & \text { Total Pages } & 36\end{array}$

Key Words Hanford, Glase Fomulaton Model, GFM, High-Level Waste Glass, HLW, Waste Oxide Loadug, HTWOS, 2009 GFM, WTP, Waste Treatment and [numobulvzation Plant

Abstract This document presents the differences between two HLW glass formulatıon models (GFM) the $1996 \mathrm{GFM}$ and the 2009 GFM A glass formulation model ts a collection of giass properiy correlations and associaied limits, as well as model valudity and solubiluty constranols, it uses the pretrealed HLW feed composition to predict the amouni and composition of glass formung additives necessary to produce acceptable lfLW glass The 2009 GFM presented in lhus report was consinucted as a nonlunear optimization calculation based on updated glass property data and solubility lumuts deseribed in PNNL-1850L (2009) Key mission drivers such as the total mass of HLW glass and waste oxide loadeng are conmared between the two glass formulation models In addition, a sensitsvity study was performed within the 2009 GFM to determine the effect of relaxing vanious constraints on the predicled mass of the HLW glass

TRADEMARK OISCLAIMER Refiersince heren to any specofic commerchal product process or seance by trade name

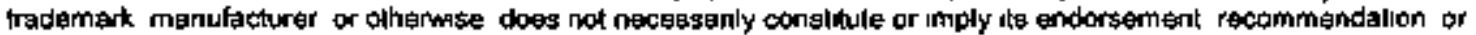
faworing by the United States Gowemment or any agency thereof or ins contractors or rubcontractors

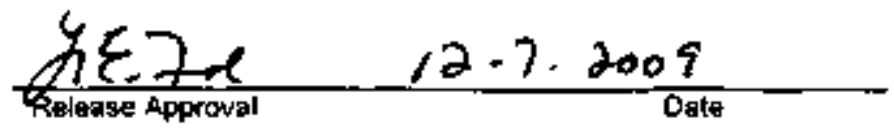

Approved For Public Release

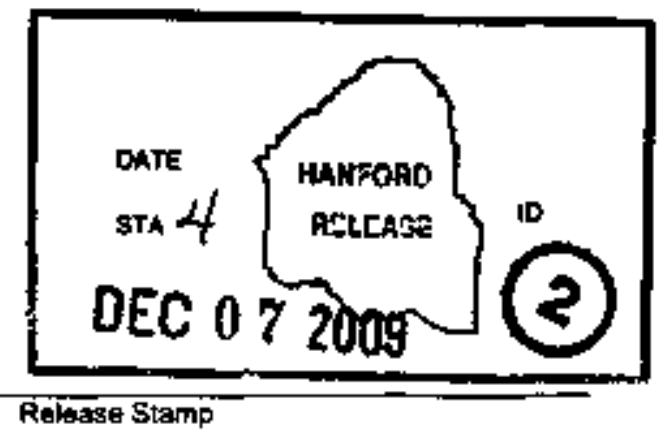

Release Stamp 


\section{DISTRIBUTION SHEET}

To

Distribution

\section{Project Titlen Work Order}

RPP-RPT-42649 Rev, 0 High-level waste Glass Formulation Model

Sensitivity study 2009 Glass Formulation Model versus 1996 Glass For
From

Fıona Meinert

\begin{tabular}{l} 
Page 1 of 2 \\
\hline Date $12 / 3 / 2009$ \\
\hline EDT No \\
\hline ECN No
\end{tabular}

Name -

\begin{tabular}{|c|c|c|c|c|}
\hline MSIN & $\begin{array}{l}\text { Text } \\
\text { With All } \\
\text { Attach }\end{array}$ & Text Only & $\begin{array}{l}\text { Altach / } \\
\text { Appendix } \\
\text { Donly }\end{array}$ & $\begin{array}{c}\text { EDT/ECN } \\
\text { Only }\end{array}$ \\
\hline & $x$ & & & \\
\hline B1-55 & $x$ & & & \\
\hline$B 1-55$ & $x$ & & & \\
\hline $\mathrm{B} 1-55$ & $x$ & & & \\
\hline R2-58 & $x$ & & & \\
\hline B1-55 & $x$ & & & \\
\hline Bl-55 & $x$ & & & \\
\hline B1-55 & $x$ & & & \\
\hline Bl-55 & $x$ & & & \\
\hline Bl-55 & $x$ & & & \\
\hline $\mathbf{K} 6-2 \mathbf{4}$ & $x$ & & & \\
\hline$K 6-24$ & $x$ & & & \\
\hline KG-24 & $x$ & & & \\
\hline \multirow{3}{*}{ K6-24 } & $x$ & & & \\
\hline & $x$ & & & \\
\hline & $x$ & & & \\
\hline$H 6-60$ & $x$ & & & \\
\hline $\mathrm{H} 6-60$ & $x$ & & & \\
\hline $146-60$ & $x$ & & & \\
\hline $1 t 6-60$ & $x$ & & & \\
\hline $\mathrm{H} 6-60$ & $x$ & & & \\
\hline $116-60$ & $x$ & & & \\
\hline B1-SS & $x$ & & & \\
\hline B1-5S & $x$ & & & \\
\hline \multirow[t]{2}{*}{$B 1-5.5$} & $x$ & & & \\
\hline & $x$ & & & \\
\hline \multirow[t]{3}{*}{$H 6-60$} & $x$ & & & \\
\hline & $\mathrm{x}$ & & & \\
\hline & $x$ & & & \\
\hline B1-55 & $\mathrm{x}$ & & & \\
\hline $\mathrm{B} 1-55$ & $\mathrm{x}$ & & & \\
\hline$B 1=55$ & $x$ & & & \\
\hline
\end{tabular}

Jeremy Belsher, belsherjolonid.orst.edu Frona Meınert

Paul Certa

Tom Crawford

$\mathrm{N} \perp \mathrm{Ck} \mathrm{K} \perp \mathrm{LCh}$

Paul Rutland

Jacob Reynolds

Gary Dunford

Dave shuford

Michele Wells

John V1enna

A. Fluegel

D.S. K1m

P. Hrma

Rod Grmpel, rfgumpelobechtel, com

Ernle Lee, edleebbechtel,com

Rob Gilbert

Julle Reddack

Al Kruger

J1ar-Shun Shuen

Glyn Trenchard

Stacy Charbonequ

Curt Rieck

Jack Cloud

Chris Burrows

Ian Pegg, Lanpevsl.cua.edu

Ben Harp

Yueying Deng, yndengebechtel.com

John Mahoney, Jlmahonedbechtel. com

Randy Krekbride

Gaxl Allen

Randy Lytle 


\section{DISTRIBUTION SHEET}

To

bistribution

\section{Project Title Work Order}

RPF-RPT-42649 Rev. 0 High-leve] waste G.lass Formulation Model

Sensitlyaty Study 2009 Glass Formulation Model versus 1996 Glass for

\section{From}

F 10 na Me $\perp$ nec L

Page 2 of 2

Date $12 / 3 / 2009$

EDT No

ECN No

\section{Ted Hohl \\ Landa Bergmann \\ kussel Jasper \\ Heter Empey \\ Jason Shunabery \\ Elizha west \\ James Foster}

Denns Lund

OST I

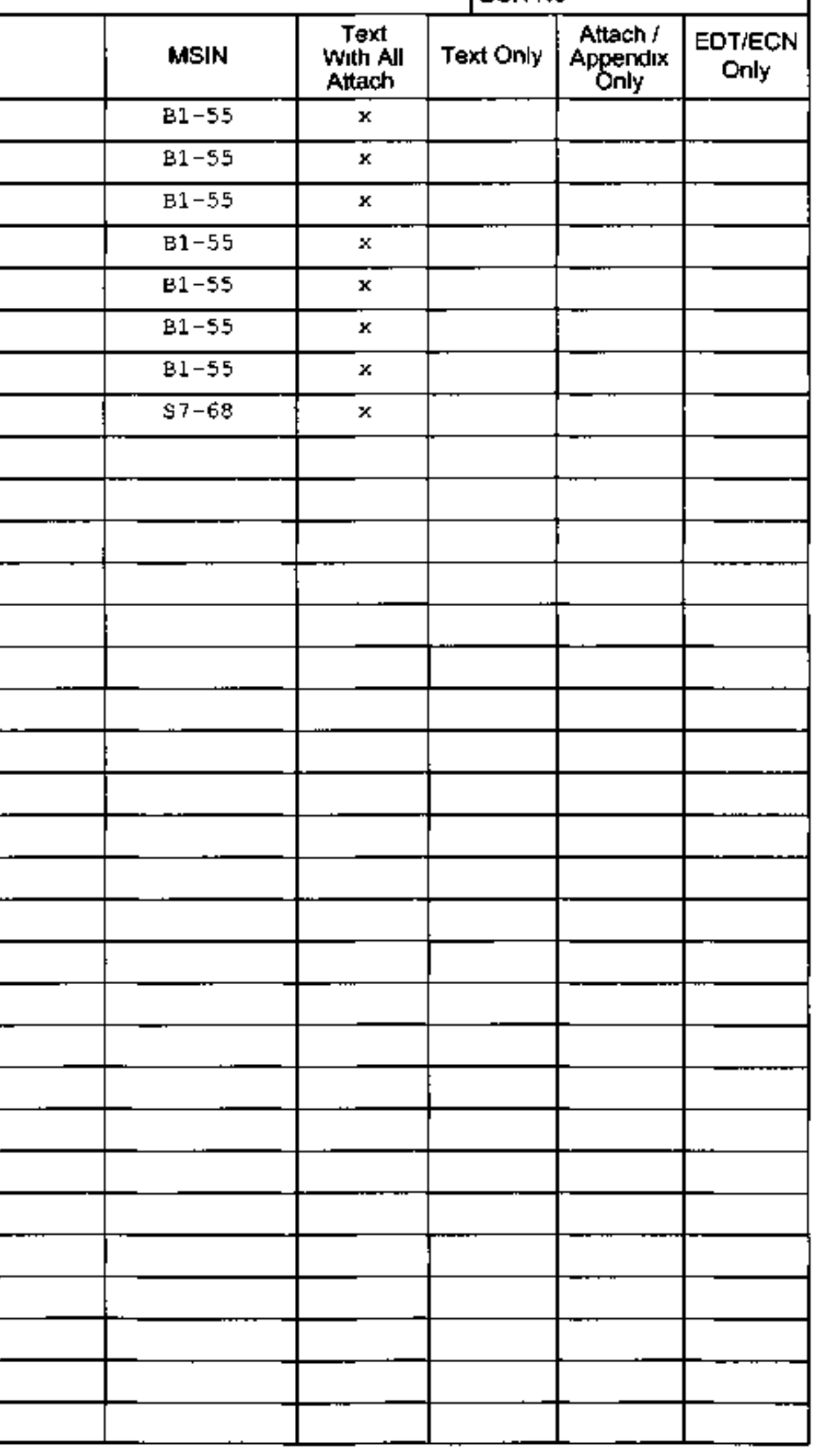


RPP-RPT-42649, Rev. 0

\section{EXECUTIVE SUMMARY}

\section{INTRODUCTION}

The Hanford Tank Waste Operations Simulator (HTWOS) is a dynamic flowsheet and mass balance model that is an essential component of the mission planning process. HTWOS models the retrieval, transfer and processing of Hanford's tank waste. A main component of HTWOS is the high-level waste (HLW) treatment plant model and the central component of the HLW treatment plant model is the HLW glass formulation model.

A glass formulation model (GFM) is a collection of empirical property correlations and their associated limits and a set of model validity and solubility limits. Given a pretreated HLW feed, the glass formulation model can predict the amount and the composition of the resulting HLW glass. This information assists in predicting mission duration and long term disposal requirements. HTWOS currently uses a glass formulation model based mostly on 1996-era glass data, herein called the 1996 GFM.

Since 1996, large amounts of glass performance and processing data have been collected. This provided the opportunity to expand the range of the validity of the glass formulation model. Also, a clearer understanding of the solubility of the HLW glass components left some of the older solubility constraints in need of updating. In late 2009, PNNL issued an updated glass formulation model (herein, called the 2009 GFM) that incorporated these improvements.

This report compares the composition and mass of the HLW glass predicted by the 2009 GFM with the predictions from the 1996 GFM. In addition, a sensitivity study was performed within the 2009 GFM to determine the effect of relaxing various constraints on the predicted mass of the HLW glass.

\section{RESULTS AND CONCLUSIONS}

The two HLW glass models predict waste glass masses that are very similar $(0.52 \%$ difference). The 1996 GFM predicts a waste glass mass of 46,063 metric tons and a $30.9 \%$ waste oxide loading (WOL). The 2009 GFM predicts a slightly larger glass mass at 46,303 metric tons with a $30.5 \%$ WOL.

In order of decreasing importance, the top five glass drivers for each model are:

- 2009 GFM: $\mathrm{SO}_{3}$, nepheline discriminator, $\mathrm{T}_{1 \%}$-sp, $\mathrm{Bi}_{2} \mathrm{O}_{3}, \mathrm{Na}_{2} \mathrm{O}$

- 1996 GFM: $\mathrm{SO}_{3}, \mathrm{Al}_{2} \mathrm{O}_{3}, \mathrm{~T}_{\mathrm{L}}-\mathrm{sp}, \mathrm{Na}_{2} \mathrm{O}, \mathrm{T}_{\mathrm{L}}$-zircon

$\mathrm{SO}_{3}$ is the primary glass driver in both models. In the $1996 \mathrm{GFM}$, the $\mathrm{Al}_{2} \mathrm{O}_{3}$ validity limit is the second largest glass driver. The 2009 model relaxes the $\mathrm{Al}_{2} \mathrm{O}_{3}$ constraint and, as a result, the nepheline discriminator replaces $\mathrm{Al}_{2} \mathrm{O}_{3}$ as the second major glass driver (note that the nepheline discriminator is a function of the $\mathrm{Al}_{2} \mathrm{O}_{3}$ concentration, so $\mathrm{Al}_{2} \mathrm{O}_{3}$ is still important). The other noticeable difference is the appearance of the $\mathrm{Bi}_{2} \mathrm{O}_{3}$ model validity constraint as one of the top five glass drivers in the 2009 GFM. 
HTWOS currently shows only $1.7 \%$ of the total $\mathrm{SO}_{4}$ waste ending up in $\mathrm{HLW}$ glass (in the form of $\mathrm{SO}_{3}$, with the majority of the balance going to low-activity waste glass. Both the $1996 \mathrm{GFM}$ and the 2009 GFM model predict that $\mathrm{SO}_{3}$ solubility constraint is the prinary glass driver. There is a significant amount of uncertainty surrounding the sulfate partitioning assumptions currently used for system planning and modeling purposes. Because of $\mathrm{SO}_{3}{ }^{*} \mathrm{~s}$ role as the primary glass driver, it is worth reexamining sulfate partitioning. Small decreases or increases in the anount of $\mathrm{SO}_{4}$ reporting to the HLW melters will have dramatic effects on waste oxide loading and the final HLW glass mass. For example, $\mathrm{SO}_{3}$ no longer plays a role as a glass driver when the amount of sulfate reporting $10 \mathrm{HLW}$ is cut in half. The waste oxide loading increases from $30.5 \%$ to $36 \%$ and the total mass of glass decreases by $13 \%$ in that case. Despite these improvements, other constraints become more prominent glass drivers as $\mathrm{SO}_{3}$ "s role is diminished, particularly nepheline, $\mathrm{Bi}_{2} \mathrm{O}_{3}, \mathrm{~F}$ - and $\mathrm{P}_{2} \mathrm{O}_{5}$.

The 2009 GFM redues the anount of glass that is limited by model validity constraints. This improvement is offset by the addition of new constraints, $\mathrm{F}-$ mass fraction, $\mathrm{XC}_{\mathrm{CO}}{ }^{+} \mathrm{X}_{\mathrm{P}_{2} \mathrm{O}_{2}} . \mathrm{Bi}_{2} \mathrm{O}_{3}$ mass fraction, and $\mathrm{UO}_{3}$ mass fraction, which did not appear in the $1996 \mathrm{GFM}$. The combined effect of these two trends is the nearly static predicted average waste oxide loading between the 1996 and the 2009 GFM.

In the 2009 GFM, $\mathrm{Na}_{2} \mathrm{O}, \mathrm{P}_{2} \mathrm{O}_{5}, \mathrm{Bi}_{2} \mathrm{O}_{3}, \mathrm{SO}_{3}$ and the nepheline discriminator were identified as the constraints that were most likely to be relaxed. given additional glass fomulation work, and to provide a significant decrease in predicted waste glass mass. Of these constraithts, the effect of $\mathrm{SO}_{3}$ on the predicted glass mass was nost significant. Relaxing the $\mathrm{SO}$, solubility constraint to $1,0 \%$ by mass from $0.5 \%$ led to a $14.4 \%$ decrease in predicted waste glass mass. Even more conservative changes in the $\mathrm{SO}_{3}$ constraint resulted in a $5.7 \%$ - $11.9 \%$ teduction in predicted waste glass mass. However, this behavior and the observation tha1 $\mathrm{SO}_{3}$ is the primary glass driver night change if the sulfate partitioning assumptions change (i.e., this could be an artifact of the sulfate partitioning assumptions).

The effect of the nepheline discriminator on the waste oxide loading was significantly less than that of the $\mathrm{SO}_{3}$ constraint. Lowering the nepheline constraint to 0.45 showed a $2.6 \%$ decrease in predicted glass mass. Lowering the nepheline constraint to a more moderate value of 0.57 showed a similar decrease of $2.3 \%$ in predicted waste glass mass.

The $\mathrm{Bi}_{2} \mathrm{O}_{3}, \mathrm{Na}_{2} \mathrm{O}$ and $\mathrm{P}_{2} \mathrm{O}_{5}$ constraints have an even smaller eflect on the predicted waste glass mass. Relaxing the $\mathrm{Bi}_{2} \mathrm{O}_{3}$ constraint can lead to a $1.5 \%$ decrease in predicted waste glass mass, while relaxing either the $\mathrm{Na}_{2} \mathrm{O}$ or $\mathrm{P}_{2} \mathrm{O}_{5}$ constraints results in less than a $1 \%$ reduction in predicted waste glass mass.

Large improvements in predicted HLW glass mass will require relaxing multiple constraints or possibly a drastic change in glass fomulation, with the possible exception of $\mathrm{SO}_{3}$ which, as already stated, may be an artifact of partitioning assumptions. Relaxing multiple constraints together has a greater effect than the sum of relaxing each constraint individually. For this report, only a few runs were performed where multiple constraints were relaxed. Two runs were performed where all five constraints were relaxed, resulting in a $23.0 \%$ and $16.7 \%$ reduction in predicted glass mass; the first tun used the most relaxed values for all five constraints, while the second run used the nost relaxed values for four of the constraints and a more conservative value of $0.7 \%$ for $\mathrm{SO}_{3}$. 
The overall results suggest that it would be worthwhile to investigate relaxing the $\mathrm{SO}_{3}$ and the tephelite discriminator constraints. Although the $\mathrm{Bi}_{2} \mathrm{O}_{3}, \mathrm{Na}_{2} \mathrm{O}$ and $\mathrm{P}_{2} \mathrm{O}_{5}$ constraituts have less effect on the predicted waste oxide loading, relaxing them in conjunction with the nepheline discriminat or or the $\mathrm{SO}_{3}$ constraint will provide an additional decrease in predicted glass mass that is large enough to warrant an attempt to relax them. If the $\mathrm{T}_{1 \%}$ - spinel constraint was altered, it is likely that the empirical property correlation itself. as opposed to the property linit, would be changed, or the $\mathrm{T}_{1 \%}$-spinel constraint would be outright replaced with a different property constraint. For this reason, the effect of varying the $T_{1 \%}$ - spinel constraint was not examined in this study. The $\mathrm{T}_{1 \%}-$ spinel constraint does limit the waste oxide loading in $13.5 \%$ of the waste glass. so any change that makes it more permissive could yield noticeable improvements in waste oxide loading. 


\section{TABLE OF CONTENTS}

1.0 OBJECTIVE................................................................................................ 1

20 SLTMMARY OF RESULTS AND CONCLLISION .......................................................... 2

3.0 INTRODUCTION'BACKGROLND ..................................................................... 3

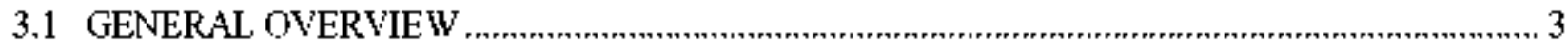

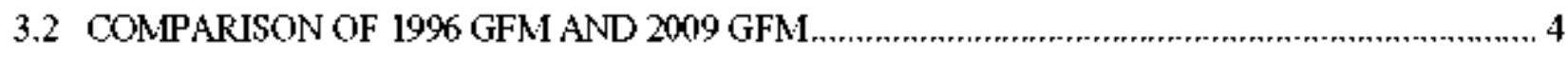

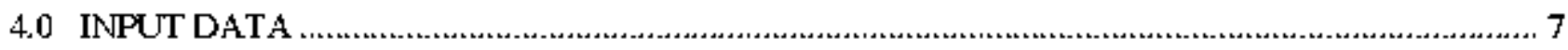

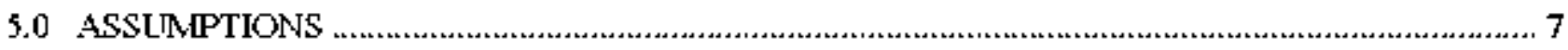

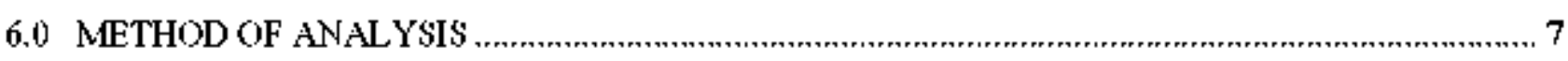

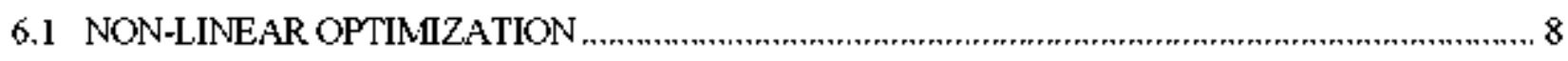

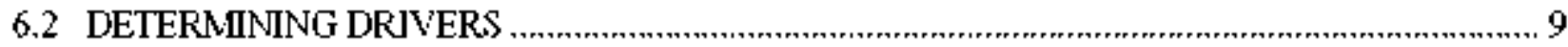

6.3 SENSITIVITY STUDY WTTHIN NEW MODEL ............................................................ 10

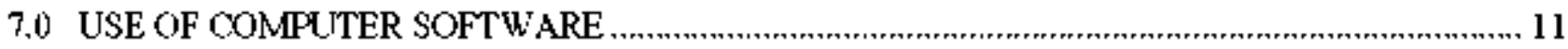

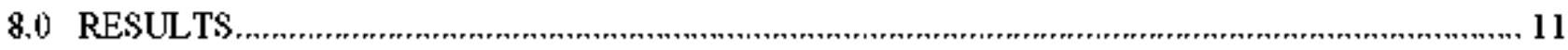

8.1 COMPARISON OF 2009 AND 1996 GFM RESLLTS ......................................................... 11

8.2 SENSITIVITY STUDY FOR NEW MODEL ........................................................... 20

9.0 CONCLUSIONS ........................................................................................ 27

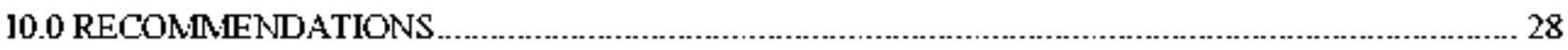

11.0 REFERENCES .................................................................................................... 29

\section{LIST OF FIGURES}

Figure 8-1 Waste Oxide Loading ......................................................................13

Figure 8-2 Comparison of Waste Oxide Loading .............................................. 14

\section{LIST OF TABLES}

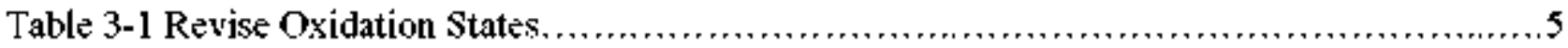

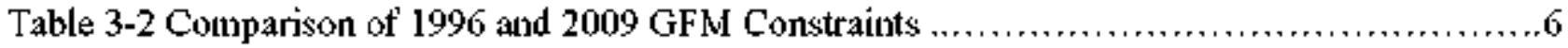

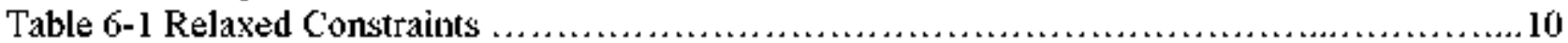

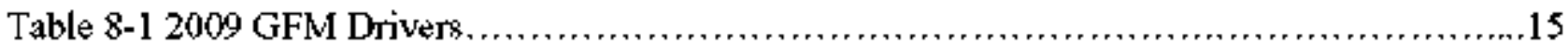

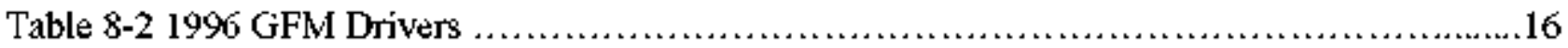

Table 8-3 2009 GFM Drivers that Predict more than a $5 \%$ increase in IHLW Mass............... 18

Table 8-4 Comparison of Drivers........................................................ 19

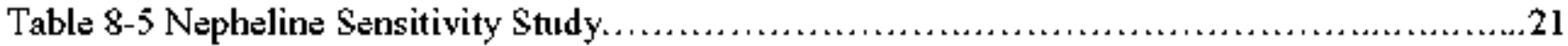

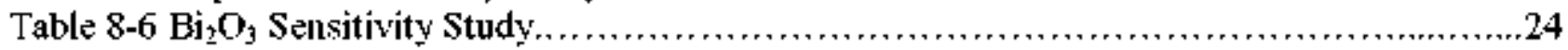

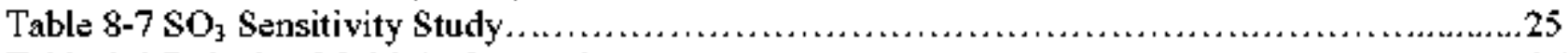

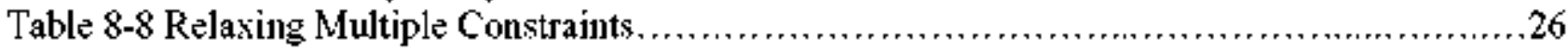


RPP-RPT-42649, Rev, 0

\section{ABBREVIATIONS AND ACRONYMS}

$\begin{array}{ll}\text { GFM } & \text { Glass Formulation Model } \\ \text { HLW } & \text { High Level Waste } \\ \text { HTWOS } & \text { Hanford Tank Waste Operations Simulator } \\ \text { PCT } & \text { Product Consisiency Test } \\ \text { PNNL } & \text { Pacific Northwest National Laboratory } \\ \text { WTP } & \text { Waste Treatment Plant } \\ \text { WOL } & \text { Waste Oxide Loading }\end{array}$


RPP-RPT-42649, Rev. 0

\subsection{OB.JECTIVE}

An essential tool in Hanford's system planning processes is the dynamic flowsheet and mass balance model, the Hanford Tank Waste Operations Simulator (HTWOS). HTWOS models the disposal. retrieval, staging and treatment of Hanford's tank waste. HTWOS is essential for predicting mission duration and for evaluating the effectiveness of proposed treatment strategies. The waste treatment mission can be no shorter than the time required for treating the HLW fraction of the tank waste. Since the treatment method is vitrification, it is important to be able to project the quantity of HLW glass as a function of pretreated waste composition. A core piece of the HTWOS model is the HLW treatment plant model and a central part of the HLW treatment model is the HLW glass formulation model.

A glass formulation model (GFM) is a collection of glass property correlations and associated limits, as well as model validity and solubility constraints. The model uses the composition of the pretreated waste feed to predict the mass of the resulting vitrified HLW glass and the required glass forming additives. HTWOS currently uses a glass formulation model that is based on WHC-SD-WM-TI-768 and PNNL-11790. Two variants of the HTWOS model exist: the "Default Glass Properties Model" and the "Relaxed Glass Properties Model." The latter is the current baseline model for system planning purposes; it resulted from additional glass formulation research which followed the 1996 PNNL report but preceded the more significant changes that produced the 2009 model (details of the three constraints that were relaxed are documented in ORP-11242 Rev.4). This report uses the "Relaxed Glass Properties Model" and refers to it as the "1996 GFM."

Since 1996, large amounts of glass property data have been collected, directly or indirectly in support of the Waste Treatment and Immobilization Plant and lifecycle mission planning. This provided the opportunity to expand the range of glass compositions for which the glass property models are valid and a clearer understanding of the solubility of the waste glass constituents allowed the solubility constraints from the 1996 GFM to be replaced with more accurate limits. Details of the updated glass property models, which incorporate both the increased range of glass property data and the more accurate solubility limits, are documented in PNNL-18501, Glass Property Data and Models for Estimating High-Level Waste Glass Voltume, prepared by Vienna, et al. In this study, this new glass model is referred to as the "2009 GFM."

Formulation of the glass requires determining the proper amounts of glass forming additives to be added to the pretreated HLW waste so that the resulting glass satisfies the various constraints imposed by the glass formulation model. Both the HTWOS model and this paper approach this as a constrained, non-linear programming problem, with the goal being to minimize the mass of the glass forming additives.

The objective of this report is to perform a sensitivity study comparing the old HLW glass formulation model (described in WHC-SD-WM-TI-768 Rev 0 (1996) and PNNL-11790 (1999) applying the relaxed limits described in ORP-11242 Rev.4) against the new HLW glass formulation model (described in PNNL-18501 (2009)). This report will also look at the effects of relaxing various constraints within the 2009 HLW glass formulation model. 
RPP-RPT-42649, Rev, 0

\subsection{SUMMARY OF RESULTS AND CONCLUSION}

The two HLW glass models predict waste glass masses that are very similar (0.52\% difference). The 1996 GFM model predicts a waste glass mass of 46,063 metric tons and a $30.9 \%$ WOL. The 2009 GFM predicts a slightly larger glass mass at 46,303 metric tons with a $30.5 \%$ waste oxide loading.

$\mathrm{SO}_{3}$ is the primary glass driver in both models. In the $1996 \mathrm{GFM}$ the $\mathrm{Al}_{2} \mathrm{O}_{3}$ limit is the second largest glass driver. The 2019 model relaxes the $\mathrm{Al}_{2} \mathrm{O}_{3}$ constraint and, as a result, the nepheline discriminator replaces $\mathrm{Al}_{2} \mathrm{O}_{3}$ as the second major glass driver (note that the nepheline discriminator is a function of the $\mathrm{Al}_{2} \mathrm{O}_{3}$ concentration, so $\mathrm{Al}_{2} \mathrm{O}_{3}$ is still important). The other noticeable difference is the appearance of the $\mathrm{Bi}_{2} \mathrm{O}_{3}$ model validity constraint as one of the top five glass drivers in the 2009 GFM.

It order of decreasing importance, the top five glass drivers for each model are:

- 2009 GFM: $\mathrm{SO}_{3}$, nepheline discriminator, $\mathrm{T}_{1 \%-\mathrm{sp}}, \mathrm{Bi}_{2} \mathrm{O}_{3}, \mathrm{Na}_{2} \mathrm{O}$

- 1996 GFM: $\mathrm{SO}_{3}, \mathrm{Al}_{2} \mathrm{O}_{3}, \mathrm{~T}_{\mathrm{L}}-\mathrm{sp} . \mathrm{Na}_{2} \mathrm{O}, \mathrm{T}_{\mathrm{L}}$-zircon

Although only $1.7 \%$ of the waste $\mathrm{SO}_{4}$ ends up in the HLW glass, both the $1996 \mathrm{GFM}$ and 2009 GFM nodel predict that $\mathrm{SO}_{3}$ is the printary glass driver. However, due to the uncertainties surrounding the sulfate partitioning assumptions currently used for system planning and modeling purposes, it would be worthwhile to reesanine sulfate partitioning. Even suall errors in these partitioniog assumptions could result in significant errors in predicted HLW glass mass.

The 2009 GFM redices the amount of glass that is limited by nodel validity constraitsts. This improvement is offset by the addition of new constraints. $\mathrm{F}^{-}$mass fraction. $\mathrm{X}_{\mathrm{CaO}^{\circ}} \mathrm{X}_{\mathrm{F}_{2} \mathrm{O}}, \mathrm{Bi}_{2} \mathrm{O}_{3}$ mass fraction and $\mathrm{UO}_{3}$ mass fraction, which predict a decreased WOL on a batch-by-balch basis and did not appear in the 1996 GFM. The combined effect of these two trends is the nearly static predicted average waste oxide loading between the 1996 and the 2009 GFMs.

In the $2009 \mathrm{GFM}, \mathrm{Na}_{2} \mathrm{O} . \mathrm{P}_{2} \mathrm{O}_{3}, \mathrm{Bi}_{2} \mathrm{O}_{3}, \mathrm{SO}_{3}$ and the nepheline discriminator were identified as the constraints tha1 were most likely to be relaxed. given additional glass formulation work and to provide a significant decrease in predicted waste glass mass. Of these constraints, the effect of $\mathrm{SO}_{3}$ on the predicted glass mass was most signiticant. Relaxing the $\mathrm{SO}_{3}$ solubility constraint to $1.0 \% \mathrm{by}$ mass from $0.5 \%$ led to a $14.4 \%$ decrease in predicted wasie glass mass. Even more conservative changes in the $\mathrm{SO}_{3}$ constraint resulted in a $5.7 \%-11.9 \%$ reduction in predicted waste glass mass.

The effect of the nepheline discriminator on the waste oxide loading was significantly less than that of the $\mathrm{SO}_{3}$ constraint. Lowering the nepheline constraint to 0.45 showed a $2.6 \%$ desrease in predicted glass mass. Lowering the nepleline constraint to a more moderate value of 0.57 showed a similar decrease of $2.3 \%$ in predicted waste glass mass.

The $\mathrm{Bi}_{2} \mathrm{O}_{3}, \mathrm{Na}_{2} \mathrm{O}$ and $\mathrm{P}_{2} \mathrm{O}_{5}$ constraints have an even smaller effect on the predicted waste glass mass. Relaxing the $\mathrm{Bi}_{2} \mathrm{O}_{3}$ constraint from $3.2 \%$ to $6.7 \%$ leads 10 a $1.5 \%$ decrease in predicted waste glass mass, while relaxing either the $\mathrm{Na}_{2} \mathrm{O}$ or $\mathrm{P}_{2} \mathrm{O}_{5}$ constraints results in less than a $1 \%$ reduction in predicted waste glass mass.

Relaxing multiple constraints together has a greater effect than the sum of relaxing each constraint individually. For this report. only a few runs were performed where multiple constraints were 
relaxed. The study is far from exhanstive in this tegard; however, the results are promising. Two runs were performed in which all five constraints were relaxed; this resulted in a $23.0 \%$ and $16.7 \%$ reduction in predicted glass mass.

The overall results suggest that it would be worthwhile to investigate relaxing the $\mathrm{SO}_{3}$ and the nepheline discriminator constraints. Although the $\mathrm{Bi}_{2} \mathrm{O}_{3}, \mathrm{Na}_{2} \mathrm{O}$ and $\mathrm{P}_{2} \mathrm{O}_{5}$ constraints have less effect on the predicted waste oxide loading. relaxing them in conjunction with the nepheline discrininator or the $\mathrm{SO}_{3}$ constraint will provide an additional decrease in predicted glass mass that is large enough to warrant an attempt to relax them. The effect of varying the $T_{1 \%}-$ spinel constraint was not examined in this study, but because it limits the waste oxide loading in $13.5 \%$ of the waste glass, any change that made the constraint more permissive could yield noticeable improvements in waste oxide loading.

\subsection{INTRODUCTION/BACKGROUND}

\subsection{GENERAL OVERVIEW}

The final waste glass produced by the HLW Vitrification Facility must meet certain criteria to be considered acceptable glass. For the purposes of this report, an acceptable glass is one that meets specific composition and property constraints. Additional criteria such as canister fill volume and heat generation are outlined in the WTP contract (DE-AC27-01RV14136) but are outside of the scope of this report. This study focuses on the subset of criteria that are directly related to the composition and properties of the glass. Those criteria are organized into three broad categories: solubility constraints, model validity constraints and proper1y constraints.

If certain crystalline solids or insoluble compounds are present in the melt they can precipitate out and collect on the bottom of the melter. This can corrode electrodes, gradually reduce the volume of the melter, or make it difficult to remove the glass from the melter. In addition, some insoluble compounds can form a scum on the top of the melt. This scum can contain high levels of harmful radionuclides and can also hinder the melting process. Solubility limits are constraints that minimize or eliniuate the dangers of melter damage due to different or immiscible phases. Solubility constraints are generally expressed as a limit on the mass fraction of a compound in the waste glass.

The glass itself must have certain properties to be processed in the melter. For example, if the glass has too high of a viscosity, it can be difficult to process; if it has too low of a viscosity, it can be cortosive to the melter. Glass waste nust also be chemically durable. The planned long term disposal of the waste glass in a geological repository makes it possible that the waste glass will be exposed to water. The waste glass nust be able resist the corrosive effects of extensive contact with water. To ensure proper chemical durability, the final glass waste mus1 meet product consistency test (PCT) constraints. These processing and acceptability constraints are grouped as property constraints. The property constraints all rely on empirical data. When a component's mass fraction falls outside the range of data that was used to find the empirical components of the model, the answer that a model gives becomes suspect. For this reason, all of the property models have model validity constraints. The model is only known to be reliable when the compositjon of the glass is 
within certain limits. Components whose mass fraction is linited in this way are included under the category of model validity constraints.

WTP is currently using six different glass forning additives $\left(\mathrm{Al}_{2} \mathrm{O}_{3}, \mathrm{~B}_{2} \mathrm{O}_{3}, \mathrm{Fe}_{2} \mathrm{O}_{3}, \mathrm{Li}_{2} \mathrm{O}, \mathrm{Na}_{2} \mathrm{O}\right.$, and $\mathrm{SiO}_{2}$ ) and has the ability to use up to 11 different glass formers. The glass fomers are added to the feed stream so that the glass will meet all solubility. model validity, and property constraints. Due to the high cost of the vitrification process and disposal, there is a large incentive to reduce costs when possible. A simple method of taking economic factors into consideration is to reduce the mass of waste glass - the batch is optimized so that the mass of the added glass forming additives is minimized. Often these constraints do not uniquely determine the waste oxide composition. When this occurs, additional constraints could be added to the system.

HTWOS currently employs a relatively old glass property model from 1996 (WHC-SD-WM-TI-768 Rev 0) and 1999 (PNNL - 11790), along with certain relaxed linjts described in ORP-11242 Rev,4. Since 1996, large amounts of glass property data have been collected and the range of the validity of the glass property models has expanded. Also, a better nuderstanding of the solubility of the HLW glass constituents has led to new solubility constraints that were not used by the previous model. In light of this, a new glass property report (PNNL-1850L ) bas been issued that will ultimately be incorporated into HTWOS.

\subsection{COMPARISON OF 1996 GFM AND 2009 GFM}

The 2009 GFM relaxes some of the model validity constraints that are used by the 1996 GFM and is conseguently applicable for a larger composition tange than the $1996 \mathrm{GFM}$. More information about the solubility of the feed constituents was also incorporated into the new model. A comparison of the 1996 and 2009 constraints is displayed in Tuble 3-2. The most notable changes are the relaxation of some of the composition limits. The upper linits for $\mathrm{Al}_{2} \mathrm{O}_{3}, \mathrm{Fe}_{2} \mathrm{O}_{3}$ and $\mathrm{Na}_{2} \mathrm{O}$ luve been increased while the lower limit for $\mathrm{SiO}_{2}$ has been relaxed. A clearer understanding of WTP recjuirements has lead to the replacement of the spinel lijuidus lemperature constraint with an equilibrium volume of $1 \%$ percent of erystals at $950^{\circ} \mathrm{C}$ constraint. In addition, to prevent undesirable phase separation, new solubility constraints on the mass fraction of $\mathrm{F}^{*}$ and the mass fraction of $\mathrm{CaO}$ multiplied by the mass fraction of $\mathrm{P}_{2} \mathrm{O}_{5}\left(\mathrm{X}_{\mathrm{CaO}_{0}} \cdot \mathrm{X}_{22 \mathrm{OS}}\right)$ have been put into place. For this study an expanded set of glass forming additives was avajlable. HTWOS uses six glass forming additives: $\mathrm{Al}_{2} \mathrm{O}_{3}, \mathrm{~B}_{2} \mathrm{O}_{3}, \mathrm{Fe}_{2} \mathrm{O}_{3}, \mathrm{Li}_{2} \mathrm{O}, \mathrm{Na}_{2} \mathrm{O}$ and $\mathrm{SiO}_{2}, \mathrm{PNNL}-18501$ lists 12 glass forming additives that can be used by WTP; this study used 11 of these. $\mathrm{K}_{2} \mathrm{O}$, a possible glass former, was not used because the WTP is not currently setup to use it $\left(\mathrm{K}^{+}\right.$from potential recycle of $\mathrm{K}_{2} \mathrm{O}$ might poison the $\mathrm{Cs}$ ion exchange columns). In addition to the six oxides cumently used by HTWOS, this study uses $\mathrm{CaO}, \mathrm{MgO}, \mathrm{TiO}_{2}$, $\mathrm{ZnO}$, and $\mathrm{ZrO}_{2}$.

This change in glass forming additives has minimal impact on the final results. The longer list of glass formers gave the 2009 model more degress of freedom when performing the optinization calculations. Runuing the $2009 \mathrm{GFM}$ with the shorter list of oxides from the $1996 \mathrm{GFM}$ resulted in a glass mass of 46,901 metric tons. which is $1.3 \%$ more glass than was predicted using all 11 glass forming additives. Overall, the 2009 model achieved a $0.7 \%$ decrease in WOL from the $1996 \mathrm{GFM}$ when using six glass foming additives, but only a $0.4 \%$ decrease in WOL when using the full suite of 11 glass formers. The improved waste oxide loading with more additives was due to the additional degrees of freedom. In bo1h cases, the differences between the 1996 and 2009 predicted 
glass masses were small, and the conclusions of this report were drawn from the runs using all 11 glass forming additives.

In addition to the change in the glass former oxides, PNNL-18501 revised the oxidation states of 7 of the waste oxides. See Table 3-1 below for the changes.

Table 3-1. Revised Oxidation States

\begin{tabular}{|cc|}
\hline Old Oxide & New Oxide \\
\hline $\mathrm{CeO}_{2}$ & $\mathrm{Ce}_{2} \mathrm{O}_{3}$ \\
\hline $\mathrm{Co}_{2} \mathrm{O}_{3}$ & $\mathrm{CoO}$ \\
\hline $\mathrm{MnO}_{2}$ & $\mathrm{MnO}$ \\
\hline $\mathrm{Re}_{2} \mathrm{O}_{3}$ & $\mathrm{Re}_{2} \mathrm{O}_{7}$ \\
\hline $\mathrm{Ru}_{2} \mathrm{O}_{3}$ & $\mathrm{RuO}_{2}$ \\
\hline $\mathrm{Tl}_{2} \mathrm{O}_{3}$ & $\mathrm{Tl}_{2} \mathrm{O}_{3}$ \\
\hline $\mathrm{U}_{3} \mathrm{O}_{5}$ & $\mathrm{UO}_{3}$ \\
\hline
\end{tabular}

The mass of the base elements in the pretreated HLW is constant, but the mass of the associated oxygen is variable. This change in oxidation states reduced the waste oxide mass from 14,220 metric tons in the 1996 GFM to 14,141 metric tons in the new model. 
Table 3-2. Comparison of 1996 and 2009 GFM Constraints

o.

\begin{tabular}{|c|c|c|c|c|c|c|c|}
\hline \multicolumn{2}{|c|}{ Constraint } & $\begin{array}{l}1996 \text { GFM } \\
\text { Lower Limit }\end{array}$ & $\begin{array}{l}1996 \text { GFM } \\
\text { Upper Limit }\end{array}$ & $\begin{array}{c}2009 \text { GFM } \\
\text { Lower } \\
\text { Limit }\end{array}$ & $\begin{array}{c}2009 \text { GFM } \\
\text { Upper } \\
\text { Limit }\end{array}$ & 1996 GFM reference & $\begin{array}{c}2009 \text { GFM } \\
\text { reference }\end{array}$ \\
\hline \multirow{7}{*}{ Solubility Constraints } & $\mathrm{Cr}_{2} \mathrm{O}_{3}$ & & $1.00 \%$ & & $1.20 \%$ & WHC-SD-WM-TI-768 Rey 0 & PNNL-18501 \\
\hline & $\mathrm{SO}_{3}$ & & $0.50 \%$ & & $0.50 \%$ & WHC-SD-WM-TI-768 Rev 0 & PNNL-18501 \\
\hline & $\mathrm{Ru}_{2} \mathrm{O}_{3}+\mathrm{Rh}_{2} \mathrm{O}_{3}$ & & & & 1515 & & $51 / 1111$ \\
\hline & $\frac{\mathrm{PdO}+\mathrm{Rh}_{2} \mathrm{O}_{3}+\mathrm{RuO}_{2}}{\mathrm{~F}}$ & & & & $\frac{0.25 \%}{2.00 \%}$ & & $\begin{array}{l}\text { PNNL-18501 } \\
\text { PNNL-18501 }\end{array}$ \\
\hline & $\mathrm{X}_{\mathrm{C} \times 0} \cdot \mathrm{X}_{\mathrm{P} 205}$ & & & & 000065 & & PNNL-18501 \\
\hline & $\mathrm{Lin}$ & & $4.00 \%$ & & $6.00 \%$ & & PNNL-18501 \\
\hline & $\mathrm{P}_{2} \mathrm{O}_{3}$ & & $3.00 \%$ & & $2.50 \%$ & WHC-SD-WM-TI-768 Rev 0 & PNNL-18501 \\
\hline \multirow{20}{*}{ Model Validity Constraints } & $\mathrm{Al}_{2} \mathrm{O}_{3}$ & & $17 \%$ & $1.90 \%$ & $20.00 \%$ & & PNNL-18501 \\
\hline & $\mathrm{B}_{2} \mathrm{O}_{3}$ & & $20 \%$ & $4.00 \%$ & $20.00 \%$ & & PNNL-18501 \\
\hline & $\mathrm{BaO}$ & & & & $4.70 \%$ & & PNNL-18501 \\
\hline & $\mathrm{Bi}_{2} \mathrm{O}_{3}$ & & & & $3.20 \%$ & & PNNL-18501 \\
\hline & $\mathrm{CaO}$ & & & & $7.00 \%$ & & PNNL-18501 \\
\hline & $\mathrm{CdO}$ & & & & $1.50 \%$ & & PNNL-18501 \\
\hline & $\mathrm{Fe}_{2} \mathrm{O}_{3}$ & & & & $17.40 \%$ & & PNNL-18501 \\
\hline & $\mathrm{K}_{2} \mathrm{O}$ & & & & $6.00 \%$ & & PNNL-18501 \\
\hline & $\mathrm{MgO}$ & & & & $6.00 \%$ & & PNNL-18501 \\
\hline & $\mathrm{MnO}$ & & & & $7.00 \%$ & & PNNL-18501 \\
\hline & $\mathrm{Na}_{2} \mathrm{O}$ & & & 4100 & $21.40 \%$ & & PNNL-18501 \\
\hline & $\mathrm{Nd}_{2} \mathrm{O}_{3}$ & & & & $5.90 \%$ & & PNNL-18501 \\
\hline & $\mathrm{NiO}$ & & & & $300 \%$ & & PNNL-18501 \\
\hline & $\mathrm{SiO}_{2}$ & & & & $53.00 \%$ & & PNNL-18501 \\
\hline & SrO & & & & $10.10 \%$ & & PNNL-18501 \\
\hline & $\mathrm{ThO}_{2}$ & & & & $6.00 \%$ & & PNNL_-18501 \\
\hline & $\mathrm{TiO}_{2}$ & & & & $3.10 \%$ & & PNNL-18501 \\
\hline & $\mathrm{UO}_{3}$ & & & & $6.30 \%$ & & PNNL-18501 \\
\hline & $\mathrm{ZnO}$ & & & & $4.00 \%$ & & PNNL-18501 \\
\hline & $\mathrm{ZrO}_{2}$ & & $15 \%$ & & $13.50 \%$ & & PNNL-18501 \\
\hline \multirow{5}{*}{ Property Constraints } & $\eta 1150\left(\mathrm{~Pa}^{*} \mathrm{~s}\right)$ & 4.5 & $10^{1}$ & & 6 & WHC-SD-WM-TL-768 Rev 0 & PNNL-18501 \\
\hline & TL-sp $\left({ }^{\circ} \mathrm{C}\right)$ & & $1100^{1}$ & & & & $1 / 1111$ \\
\hline & $\mathrm{T}_{1 \%-\mathrm{sp}}\left({ }^{\circ} \mathrm{C}\right)$ & & & & 950 & & PNNL-18501 \\
\hline & $\mathrm{TL}-\mathrm{ZI}\left({ }^{\circ} \mathrm{C}\right)$ & & 1050 & & $1050^{\text {* }}$ & WHC-SD-WM-TI-768 Rev 0 & PNNL-18501 \\
\hline & Nepheline & & 0.62 & & 0.62 & WHC-SD-WM-TI-768 Rev 0 & PNNL-18501 \\
\hline
\end{tabular}

${ }^{1} \mathrm{Cr}_{2} \mathrm{O}_{3}$ solubility, glass viscosity, and spinel liquidus temperature constraints were relaxed from their more conservative "default" values to the values shown in this table for the "Relaxed 1996 GFM" (ORP-11242 Rev.4) The values shown are the current baseline values used for system planning and modeling purposes.

${ }^{2} \mathrm{HTWOS}$ used a lower limit of $850^{\circ} \mathrm{C}$ 
RPP-RPT-42649, REV, 0

\subsection{INPUT DATA}

The input data for this study consists of a spreadshest (SVF-1748) containing the composition of 1922 batches of pretreated HLW from the following HTWOS run:

SP4 Planuing Case-3.0-8.4r0-2009-03-30-at-20-02-39

The HTWOS model run for this spreadsheet is based on the same starting tank inventory, blending and partitioning assumptions (waler wash factors, caustic leach factors, oxidative leach endpoint, post-leach wash efficacy) as the Baseline Case in ORP-11242, Rev 4. Use of a fixed set of pretreated HLW batches ensures that changes in the degree-of-blending of the feed delivered to the WTP do not confound the interpretation of the results of this study.

The input spreadsheet also contains the predicted waste loading, formulated glass composition (prior to application of melter splits) and glass properties for each batch using the 1996 GFM.

\subsection{ASSUMPTIONS}

1. The "best" glass composition is assumed to be the one that satisfies all constraints and minimizes the amount of added glass forming compounds.

2. Volatility and entrainment can lead to the loss of compounds during the melting process. A basic method of modeling this elemental loss is to multiply the components of the HLW glass by the fraction of the component that is retained. For this calculation it was assumed that no elemental loss occurred during processing and these nelter splits were ignored.

3. Where the oxides used by the 1996 GFM and the oxides used by the 2009 GFM differed, the 2009 GFM oxides where used. A conversion factor was included in the model to account for this.

\subsection{METHOD OF ANALYSIS}

A spreadshest, 2009 High Level Waste GFM, SVF-1748, was created that calculates the waste glass composition for each of the batches of pretreated HLW. The overall glass mass and waste oxide loading was compared with the results predicted by the $1996 \mathrm{GFM}$ as documented in WTP_HLW_Glass_SP4 Planning Case-3.0-8.4r0-2009-03-30-at-20-02-39_M1.xls. The constraints that limit waste oxide loading in the 2009 GFM were compared with those from the 1996 GFM. Finally, potential areas of improvement were indentified in the $2009 \mathrm{GFM}$ and sensitivity studies were perfomied to detemine what the effects of these potential improvements would be.

This study compares the glass compositions predicted by the 2009 GFM and the 1996 GFM. Any weakness in the underlying assumptions will be reflected in the resulis of the models. This may be particularly relevant with regards to $\mathrm{SO}_{4}$ partitioning. In both GFM models, the $\mathrm{SO}_{3}$ constraint is the 
glass driver for the largest mass of waste glass. Current partitioning assumptions direct most of the $\mathrm{SO}_{4}$ to the low-level waste glass. Even slight uncertainties in these $\mathrm{SO}_{4}$ partitioning assumptions could result in the GFMs predicting HLW glass masses that are significantly larger or smaller than the actual mass of glass that is produced. If the amount of $\mathrm{SO}_{4}$ remaining in the pretreated $\mathrm{HLW}$ increases, then the $\mathrm{SO}_{3}$ limit becones more important; if it significantly decreases, then the $\mathrm{SO}_{3}$ linit becomes less important.

\subsection{NON-LINEAR OPTIMIZATION}

The solubility, model validity, and property constraints do nol in-and-of-themselves uniquely determine the composition of the waste glass. The mass of the glass formers can be adjusted so as to minimize the final mass of the waste glass subject to all of the relevant constraints. This is a classic optimization problem.

The final mass of the glass is the sum of the added glass foming compounds and the mass of waste oxide feed. The mass of the waste oxide feed is fixed, so the tinal mass of the glass can be minimized by minimizing the mass of the added glass forming compounds. This means the objective function (the function to be ninimized) is:

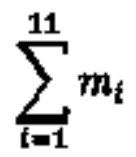

Where $m_{1}$ is the mass of the $t$-th glass forming additives. This is a linear function.

The property functions are polynomials with the components" mass fractions as the variables. For example, the equation for the viscosity at 1150 is

$$
L n\left(n_{1150}\right)=\sum_{i=1}^{19} b_{i} x_{i}+\sum_{i=1}^{2} b_{l l} x_{i}^{2}+\sum_{i=1}^{1} \sum_{j=1}^{2} b_{i j} x_{t} x_{j}
$$

Where

$$
x_{i}=\frac{m_{\text {lfeed }}+m_{\text {ladditioe }}}{m_{\text {totol }}}
$$

These constraint equations are non-linear, so even though the objective function is linear, minimizing the mass of the added glass forming compounds is a nonlinear optinization problem. There are innumerable methods of solving this type of problem numerically, but for this study the Solver add-in for Excel was used. 


\subsection{DETERMINING DRIVERS}

When conparing the 1996 and 2009 GFM it is instructive to look at the constraints that limit the waste oxide loading. It is rare for a batch to run up against a single constraint. A batch will usually meet multiple constraints. In order to detemine a unique limiting constraint for a bateh, the constraints have to be ranked. The solubility constraints are given priority. followed by the model validity constraints. Any batch that is not limited by either of two types of constraints will be linited by the property constraints.

The solubility constraints are "hard" constraints. There is a fixed anount of the solubility-liniting components in the waste feed and these amounts will determine the minimum mass of glass foming additives that can be added if the waste glass is to meet all constraints. For instance, the waste feed for batch 356 has $76.97 \mathrm{Kg}$ of $\mathrm{SO}_{3}$. The $2009 \mathrm{GFM}$ limits $\mathrm{SO}_{3}$ to $0.5 \%$ of the final mass of the waste glass. This sets the lower linit of the wasie glass mass at $76.97 \mathrm{~kg} / .005=15394 \mathrm{~kg}$. This is a limit that cannot be circumvented by altering the ratios of the added glass forming additives.

The model validity limits are also hard limits, so if they are hit, they uniquely determine the ninimum mass of the waste glass. Unlike the solubility constraints, the model validity constraints represent epistemic limitations and do not necessarily reflect underlying pliysical limitations on the glass formulation. For this reason, the exeedingly rase times when a batch is limited by both mode] validity constraints and solubility constraints, solubility constraints are reported as the primary constraint on the waste oxide loading.

Both the solubility and model validity constraints involve components that can be added as glass forming compounds. When one of these components hits a constraint and it has been added as a glass forming compound, it is not treated as a hard consiraint. In cases where a batch hits a model validity or a solubility constraint and it has been added as a glass forming compound, one of two situations apply:

- The fiual nuass of the waste glass has been detemined by another hard solubility or model validity constraint and the remaining degrees of freedom are used to determine the nonunicjue composition of glass forming oxides. The constraint that is hit due the added glass forming additives is the result of the application of the remaining degrees of freetom and does not uniquely determine waste oxide loading.

- When the maxinum waste oxide loading has not been limited by model or validity constraints, the glass forming additive is adjusted so that the glass balch does not violate a specific property constraint. Although the added glass foming compound hits a constraint, the property constraint is what is limiting the waste oxide loading and the property constraint is reported as the glass driver.

It short. model validity or solubility constraints are only reported as glass drivers if they have not been added as a glass forming compound 
The glass properties are the function of most, if not all, of the components that can be added as glass formers. This gives the model large amounts of flexibility in determining the most efficient way to meet property constraints. Because of this flexibility, the property constraints are limiting only if the batch is not limited by model validity or solubility constraints.

\subsection{SENSITIVITY STUDY WITHIN NEW MODEL}

Sensitivity studies were performed using the 2009 GFM to assess the potential impacts of relaxing certain constraints. This information might be useful in shaping future glass formulation efforts. When determining which constraints to relax, two factors were considered. First, the constraint had to play a fairly significant role in limiting waste oxide loading. It would be unproductive to improve a constraint that limited the waste oxide loading in only $0.1 \%$ of the total predicted glass mass. Second, the constraint had to have the potential to be improved in practice. There is no reason to see what the improvement in WOL would be if a constraint was relaxed if there was no possibility of that constraint being relaxed in reality.

The first consideration was achieved by calculating the glass resulting from the pretreated HLW batches with the spreadsheet. The glass drivers were determined and the constraints that had a significant impact on the final glass mass were identified. The second consideration was slightly more subjective. Glass Property Data and Models for Estimating High-Level Waste Glass Volume PNNL-18501 gave a sense of what constraints might be improved with additional glass formulation effort. After this, the primary author of the report, John Vienna, was consulted and suggested the potential areas of improvement as shown in Table 6-1.

Table 6-1. Relaxed Constraints

\begin{tabular}{c|cccl}
\hline Constraint & $\begin{array}{c}\text { Current } \\
\text { Value }\end{array}$ & $\begin{array}{c}\text { Potential } \\
\text { Value }\end{array}$ & $\begin{array}{c}\text { Percent of Class } \\
\text { Limited by } \\
\text { constraint }\end{array}$ & \multicolumn{1}{c}{ Reference } \\
\hline Nepheline & .62 & .45 & $22.5 \%$ & PNNL-18501 Appendix A \\
$\mathrm{SO}_{3}$ & $.5 \%$ & $1.0 \%$ & $36.3 \%$ & Personal Communication \\
$\mathrm{Bi}_{2} \mathrm{O}_{3}$ & $3.2 \%$ & $16.37 \%$ & $7.5 \%$ & PNNL-10987 \\
$\mathrm{Na}_{2} \mathrm{O}$ & $21.4 \%$ & $23.0 \%$ & $5.2 \%$ & VSL-06R6480-3 \\
$\mathrm{P}_{2} \mathrm{O}_{3}$ & $2.5 \%$ & $4.5 \%$ & $3.7 \%$ & Personal Communication \\
\hline
\end{tabular}

A parametric study was performed on the nepheline discriminator and $\mathrm{SO}_{3}$ solubility limits. The values were gradually changed from the current value to the potential value. The effects of this on the waste oxide loading and the glass drivers were examined. The goal with the $\mathrm{Bi}_{2} \mathrm{O}_{3}$ was to determine at what upper limit (up to $16.37 \%$ ) $\mathrm{Bi}_{2} \mathrm{O}_{3}$ was no longer a glass driver. The constraint was relaxed until that point was identified rather than varied over the entire range of potential model validity values for $\mathrm{Bi}_{2} \mathrm{O}_{3}$. The $\mathrm{Na}_{2} \mathrm{O}$ and $\mathrm{P}_{2} \mathrm{O}_{5}$ constraints were adjusted in a single step from their current value to their potential values. In addition to these variations, a few studies were performed in which several of these constraints were varied at the same time. This provided a sense of how large or small the benefits would be if improvements were made to the model. 
The $T_{1 \%}-5 p$ constraint limits $13.5 \%$ of the glass mass. It is the constraint that limits the third largest glass mass. It would be worthwhile to investigate the effect that altering the $T_{1 \%}-s p$ constraint has on the waste oxide loading. However, due to the nature of the constraint, simply altering the linit value is not a realistic reflection of how the limit would be altered if the model were to be revised. Changing the $T_{1 \%-s p}$ constraint would probably involving tedoing the underlying empirieal correlations or replacing 11 with another constraint, so it was not included in lhis study.

\subsection{USE OF COMPUTER SOFTWARE}

Excel was chosen due to its ability to perform repetitive calculations on large amounts of data and the presence of an eas y-to-use Solver add-in for constrained non-linear optimization. The current site standard versions of Excel and the Microsoflißi Windows operating system were used:

- Microsofte Excel 2007 SP1 MSO

- Microsoft(产 Windows XP Professional SP3

In addition. the following verified spreadsheets and associated Visual Basic for Applications code were used:

- 2009_HLW_GFM (SVF-1748 Rev. 2)

- 2009_GFM_SS (SVF-1755 Rev. 0)

\subsection{RESULTS}

\subsection{COMPARISON OF 2009 AND 1996 GFM RESULTS}

The anount of glass predicted by the $1996 \mathrm{GFM}$ and the $2009 \mathrm{GFM}$ was very similar (within $0.52 \%$ difference). The 2009 GFM predicted 46,303 metric tons of waste glass and a waste oxide loading of $30.5 \%$. The older model predieted a slightly smaller anount of glass waste, 46,063 metric tons. and a larger waste oxide loading at $30.9 \%$. The waste oxide loading predicted by both models is compared on a batch-by-batch basis in Figure 8-1. The models predict very similar waste oxide loading in most cases. The waste oxide loading predicted by the $2009 \mathrm{GFM}$ is plotted agaitust the waste oxide loading predicted by the 1996 GFM in Figure 8-2. As is expected the points tend to cluster around the $\mathrm{X}=\mathrm{Y}$ line.

\subsubsection{Comparison of Drivers}

Table 8-1 and Table 8-2show the glass drivers for the 1996 GFM and the 2009 GFM. The active constraints are shown on the left side of the table. The right portion of the table shows the number of batches, the average waste oxide loading of the batches, the total waste oxide mass and the total glass nass that are limited by that constraint. The latter two columms are also displayed as a percentage of the overall waste oxide mass and overall glass mass. The red shading indicates constraints for which more than $5 \%$ of the glass mass is limited by that constraint. 
The new GFM shows a slightly larger diversity of glass drivers than the 1996 model does. The 1996 GFM glass driver is limited by 10 different constraints while the 2009 GFM has 13 active constraints. The top five drivers in the 1996 GFM limit $92.4 \%$ percent of the total waste glass mass, while the top five drivers for the new model limit $85 \%$ of the final waste glass mass. 
Figure 8-1 Waste Oxide Loading

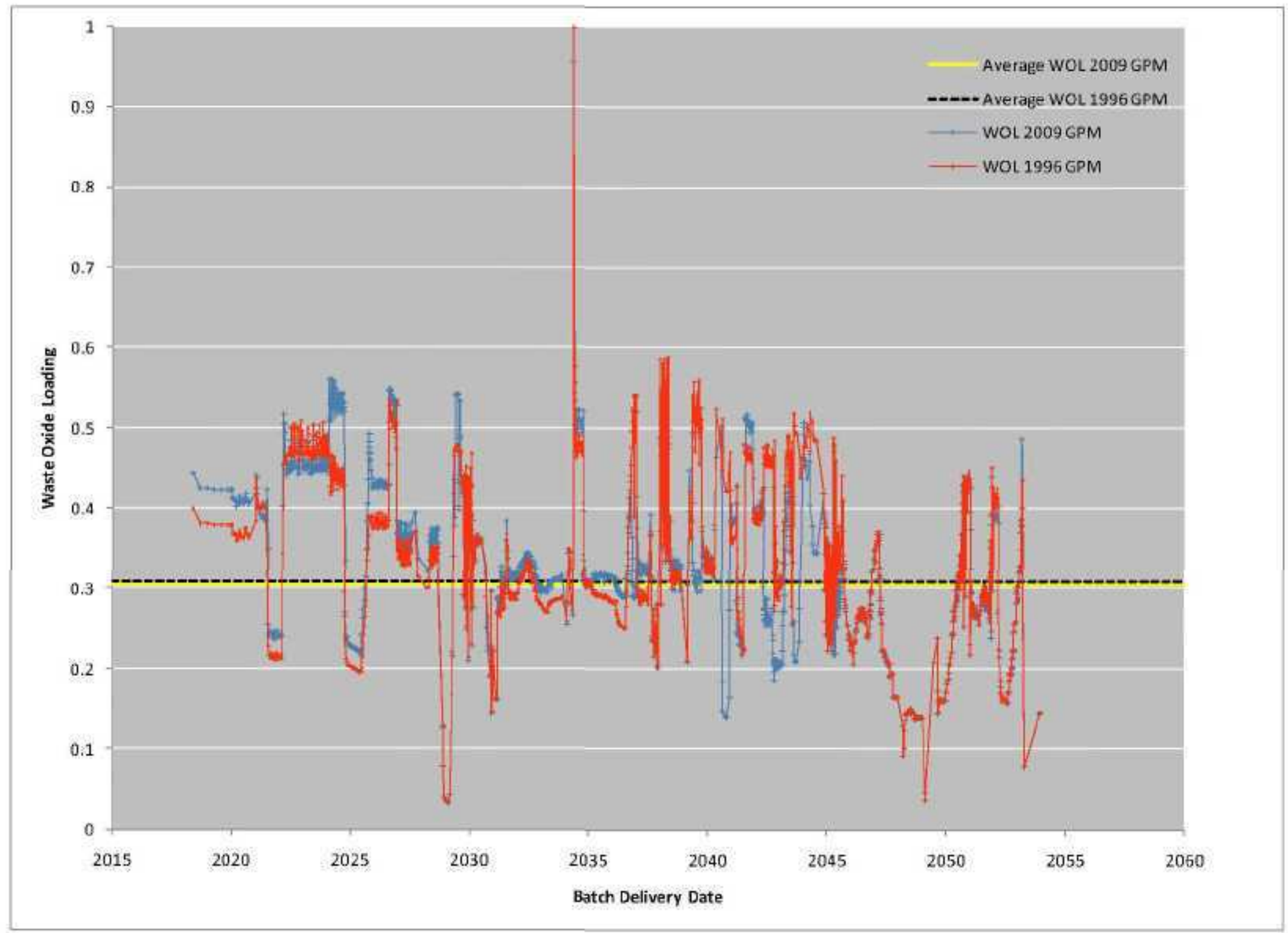


Figure 8-2 Comparison of Waste Oxide Loading

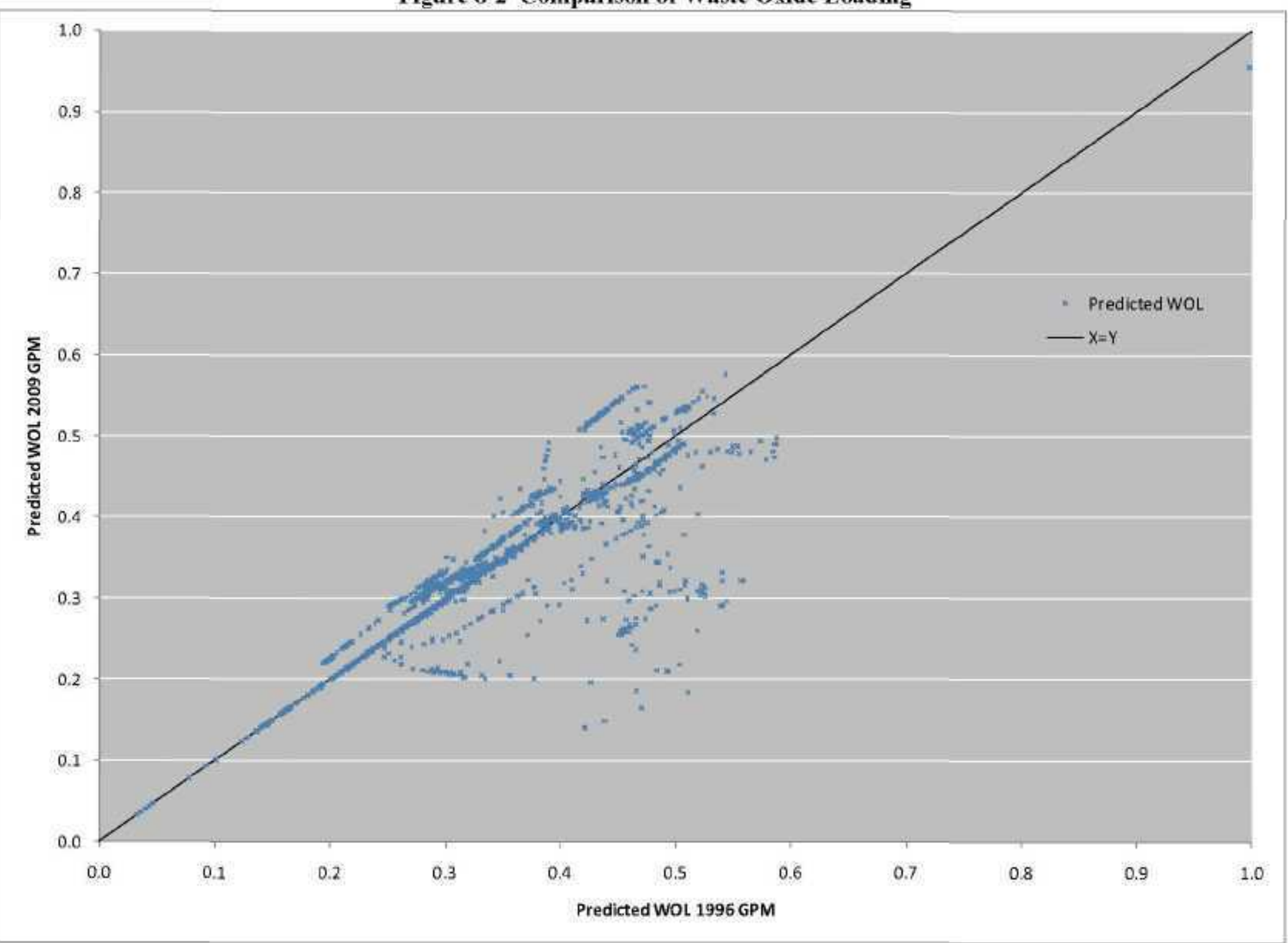


Table 8.1 2009 GFM Drivers

\begin{tabular}{|c|c|c|c|c|c|c|c|c|}
\hline \multicolumn{3}{|c|}{ Constraints } & \multirow{2}{*}{$\begin{array}{c}\text { Number } \\
\text { of } \\
\text { Batches }\end{array}$} & \multirow{2}{*}{$\begin{array}{l}\begin{array}{l}\text { Waste } \\
\text { Oxide } \\
\text { Mass } \\
\text { (MT) }\end{array} \\
3,898 \\
\end{array}$} & \multirow{2}{*}{$\begin{array}{l}\text { Glass } \\
\text { Mass } \\
\text { (MT) }\end{array}$} & \multirow{2}{*}{$\begin{array}{c}\begin{array}{c}\text { Average } \\
\text { Waste } \\
\text { Oxide } \\
\text { Loading }\end{array} \\
23.2 \% \\
\end{array}$} & \multirow{2}{*}{$\begin{array}{c}\text { Percent } \\
\text { of } \\
\text { Waste } \\
\text { Oxide } \\
\text { Mass } \\
27.6 \% \\
\end{array}$} & \multirow{2}{*}{$\begin{array}{c}\begin{array}{c}\text { Percent } \\
\text { of Glass } \\
\text { Mass }\end{array} \\
36.3 \% \\
\end{array}$} \\
\hline \multirow{19}{*}{$\begin{array}{c}\text { Glass } \\
\text { Composition } \\
\text { Constraints }\end{array}$} & \multirow{6}{*}{ Solubility Limited } & $\mathrm{SO}_{3}$ & & & & & & \\
\hline & & $\mathrm{F}$ & 43 & 337 & 1,240 & $27.1 \%$ & $2.4 \%$ & $2.7 \%$ \\
\hline & & $\mathrm{X}_{\mathrm{CaO}} \cdot \mathrm{X}_{\mathrm{P} 2 \mathrm{OS}}$ & 27 & 223 & 471 & $47.4 \%$ & $1.6 \%$ & $1.0 \%$ \\
\hline & & $\mathrm{Li}_{2} \mathrm{O}$ & 0 & 0 & 0 & $\mathrm{n} / \mathrm{a}$ & $0.0 \%$ & $0.0 \%$ \\
\hline & & $\mathrm{Cr}_{2} \mathrm{O}_{3}$ & 0 & 0 & 0 & $n / a$ & $0.0 \%$ & $0.0 \%$ \\
\hline & & Subtotal & 630 & 4,458 & 18,505 & $24.1 \%$ & $31.5 \%$ & $40.0 \%$ \\
\hline & \multirow{13}{*}{$\begin{array}{c}\text { Model Validity } \\
\text { Limited }\end{array}$} & $\mathrm{Al}_{2} \mathrm{O}_{3}$ & 0 & 0 & 0 & $n / a$ & $0.0 \%$ & $0.0 \%$ \\
\hline & & $\mathrm{B}_{2} \mathrm{O}_{3}$ & 0 & 0 & 0 & $n / a$ & $0.0 \%$ & $0.0 \%$ \\
\hline & & $\mathrm{Bi}_{2} \mathrm{O}_{3}$ & 124 & 926 & 3,464 & $26.7 \%$ & $6.5 \%$ & $7.5 \%$ \\
\hline & & $\mathrm{CaO}$ & 0 & 0 & 0 & $n / a$ & $0.0 \%$ & $0.0 \%$ \\
\hline & & $\mathrm{CdO}$ & 9 & 87 & 222 & $39.1 \%$ & $0.6 \%$ & $0.5 \%$ \\
\hline & & $\mathrm{Fe}_{2} \mathrm{O}_{3}$ & 0 & 0 & 0 & $\mathrm{n} / \mathrm{a}$ & $0.0 \%$ & $0.0 \%$ \\
\hline & & $\mathrm{SiO}_{2}$ & 0 & 0 & 0 & $\mathrm{n} / \mathrm{a}$ & $0.0 \%$ & $0.0 \%$ \\
\hline & & $\mathrm{MnO}$ & 18 & 104 & 267 & $39.0 \%$ & $0.7 \%$ & $0.6 \%$ \\
\hline & & $\mathrm{Na}_{2} \mathrm{O}$ & 127 & 881 & 2,391 & $36.9 \%$ & $6.2 \%$ & $5.2 \%$ \\
\hline & & $\mathrm{P}_{2} \mathrm{O}_{5}$ & 87 & 624 & 1,711 & $36.5 \%$ & $4.4 \%$ & $3.7 \%$ \\
\hline & & $\mathrm{UO}_{3}$ & 28 & 210 & 633 & $33.2 \%$ & $1.5 \%$ & $1.4 \%$ \\
\hline & & $\mathrm{ZrO}_{2}$ & 74 & 613 & 2,374 & $25.8 \%$ & $4.3 \%$ & $5.1 \%$ \\
\hline & & Subtotal & 467 & 3,445 & 11,062 & $31.1 \%$ & $24.4 \%$ & $23.9 \%$ \\
\hline \multirow{5}{*}{$\begin{array}{c}\text { Glass } \\
\text { Property } \\
\text { Constraints }\end{array}$} & \multicolumn{2}{|c|}{$\begin{array}{l}\text { Glass Composition Constraints } \\
\text { Subtotal }\end{array}$} & 1097 & 7,903 & 29,567 & $26.7 \%$ & $55.9 \%$ & $63.9 \%$ \\
\hline & \multicolumn{2}{|c|}{$\mathrm{T}_{1 \% \leqslant 8}$ involved } & 362 & 2.771 & 6,235 & $44.4 \%$ & $19.6 \%$ & $13.5 \%$ \\
\hline & \multicolumn{2}{|c|}{ Only TL-zr involved } & 4 & 35 & 99 & $35.1 \%$ & $0.2 \%$ & $0.2 \%$ \\
\hline & \multicolumn{2}{|c|}{ Only Nepheline } & 459 & 3.431 & 10.402 & $33.0 \%$ & $24.3 \%$ & $22.5 \%$ \\
\hline & \multicolumn{2}{|c|}{ Glass Property Constraints Subtotal } & 825 & 6,237 & 16,736 & $37.3 \%$ & $44.1 \%$ & $36.1 \%$ \\
\hline & Total & & 1922 & 14,141 & 46,303 & $30.5 \%$ & $100.0 \%$ & $100.0 \%$ \\
\hline
\end{tabular}


Table 8-2 1996 GFM Drivers

\begin{tabular}{|c|c|c|c|c|c|c|c|c|}
\hline \multicolumn{3}{|c|}{ Constraints } & \multirow{2}{*}{$\begin{array}{c}\begin{array}{c}\text { Number } \\
\text { of waste } \\
\text { feed } \\
\text { batches }\end{array} \\
629\end{array}$} & \multirow{2}{*}{$\begin{array}{l}\begin{array}{l}\text { Waste } \\
\text { oxide } \\
\text { mass } \\
\text { (MT) }\end{array} \\
4,442\end{array}$} & \multirow{2}{*}{$\begin{array}{c}\text { Glass } \\
\text { mass } \\
(\mathrm{MT})\end{array}$} & \multirow{2}{*}{$\begin{array}{c}\begin{array}{c}\text { Average } \\
\text { waste }\end{array} \\
\text { loading in } \\
\text { glass }\end{array}$} & \multirow{2}{*}{$\begin{array}{c}\begin{array}{c}\text { Percent } \\
\text { of waste } \\
\text { oxide } \\
\text { mass }\end{array} \\
31.2 \%\end{array}$} & \multirow{2}{*}{$\begin{array}{c}\begin{array}{c}\text { Percent } \\
\text { of glass } \\
\text { mass }\end{array} \\
39.3 \%\end{array}$} \\
\hline \multirow{10}{*}{$\begin{array}{l}\text { Glass } \\
\text { composition } \\
\text { constraints }\end{array}$} & \multirow{4}{*}{ Solubility limited } & $\mathrm{SO}_{3}$ & & & & & & \\
\hline & & $\mathrm{P}_{2} \mathrm{O}_{5}$ & 91 & 648 & 1,815 & 0.357 & $4.6 \%$ & $3.9 \%$ \\
\hline & & $\mathrm{Cr}_{2} \mathrm{O}_{3}$ & 15 & 91 & 222 & 0.410 & $0.6 \%$ & $0.5 \%$ \\
\hline & & Subtotal & 735 & 5,182 & 20,141 & 0.257 & $36.4 \%$ & $43.7 \%$ \\
\hline & \multirow{5}{*}{$\begin{array}{l}\text { Model validity } \\
\text { limited }\end{array}$} & $\mathrm{Al}_{2} \mathrm{O}_{3}$ & 433 & 3,323 & 11,034 & 0.301 & $23.4 \%$ & $24.0 \%$ \\
\hline & & $\mathrm{Fe}_{2} \mathrm{O}_{3}$ & 45 & 383 & 1,005 & 0.381 & $2.7 \%$ & $2.2 \%$ \\
\hline & & $\mathrm{Na}_{2} \mathrm{O}$ & 211 & 1,515 & 4,055 & 0.374 & $10.7 \%$ & $8.8 \%$ \\
\hline & & $\mathrm{SiO}_{2}$ & 0 & 0 & 0 & $\mathrm{n} / \mathrm{a}$ & $0.0 \%$ & $0.0 \%$ \\
\hline & & Subtotal & 689 & 5,221 & 16,095 & 0.324 & $36.7 \%$ & $34.9 \%$ \\
\hline & \multicolumn{2}{|c|}{$\begin{array}{c}\text { Glass composition constraints } \\
\text { subtotal }\end{array}$} & 1,424 & 10,402 & 36,236 & 0.287 & $73.2 \%$ & $78.7 \%$ \\
\hline \multirow{4}{*}{$\begin{array}{l}\text { Glass } \\
\text { property } \\
\text { constraints }\end{array}$} & \multicolumn{2}{|c|}{ Only Spinel $T_{\mathrm{L}}$ involved } & 399 & 3,002 & 6,606 & 0.454 & $21.1 \%$ & $14.3 \%$ \\
\hline & \multicolumn{2}{|c|}{ Zirc $T_{L}$ involved } & 76 & 630 & 2,772 & 0.227 & $4.4 \%$ & $6.0 \%$ \\
\hline & \multicolumn{2}{|c|}{ Neither $T_{\mathrm{L}}$ involved } & 23 & 186 & 449 & 0.414 & $1.3 \%$ & $1.0 \%$ \\
\hline & \multicolumn{2}{|c|}{ Glass property constraints subtotal } & 498 & 3,818 & 9,827 & 0.388 & $26.8 \%$ & $21.3 \%$ \\
\hline \multicolumn{3}{|c|}{ Total } & 1,922 & 14,220 & 46,063 & 0.309 & $100.0 \%$ & $100.0 \%$ \\
\hline
\end{tabular}


One of the goals of the new glass model was to reduce the number batches that were limited by model validity constraints. It met this goal. In the previous mode l, 34.9\% (by final weight percent) of the glass was limited by model validity constraints. In the new model, this number was significantly reduced to $23.9 \%$. Since the $2009 \mathrm{GFM}$ predicted a smaller number of batches limited by model validity constraints, it would be expected to also predict a smaller final waste glass mass: instead, the two models predict very similar waste glass masses. The 2009 GFM predicted reduced waste mass in regards to model validity constraints, so in order to predict a similar final glass mass, it nust predict a bigher glass mass elsewhere. Table 8-3 was developed to belp explain the changes (or lack thereof) in glass mass.

Table 8-3 shows the glass drivers for batches where the 2009 GFM predicted more that a $5 \%$ larger glass mass than the $1996 \mathrm{GFM}$. A vast majority of cases are the result of the $\mathrm{UO}_{3} \mathrm{~F}^{-}, \mathrm{X}_{\mathrm{COO}} \cdot \mathrm{X}_{\mathrm{P} 205}$ $\mathrm{P}_{2} \mathrm{O}_{5}$ and $\mathrm{Bi}_{2} \mathrm{O}_{3}$ constraints. The $\mathrm{F}$ - and $\mathrm{X}_{\mathrm{COO}^{+}} \mathrm{X}_{\mathrm{P} 2 \mathrm{O}}$ constraints are solubility constraints that were not used in the $1996 \mathrm{GFM}$. The $\mathrm{LO}_{3}$ and $\mathrm{Bi}_{2} \mathrm{O}_{3}$ model validity constraints were not included in the previous model either. $\mathrm{P}_{2} \mathrm{O}_{5}$ was a constraint in the 1996 GFM, but the constraint was less restrictive at $3.0 \%$ than the $2.5 \%$ limit used by the 2009 GFM. The very similar predicted glass mass between the two models, despite a general decrease in the anount of glass limited by model validity constraints, is the result of these new constraints.

In hoth the 1996 and 2009 GFM, SOy is the largest glass driver on a batch number basis and as a percentage of the total glass mass. The older model predicted a larger tolal glass mass limited by $\mathrm{SO}_{3}(39.3 \%)$ than the new model $(36.3 \%)$. The $\mathrm{SO}_{4}$ partitioning assumptions used to determine the composition of the pretreated HLW result in about $1.7 \%$ of the waste $\mathrm{SO}_{4}$ reporting to the $\mathrm{HLW}$ glass with most of the remaining $98.3 \%$ reporting to the L4W glass. Small enors in these partitioning assumptions could result in significant errors in predicted HLW glass mass. For example, if the amount of residual $\mathrm{SO}_{3}$ in the pretreated HLW were cul in half, the mass of the resulting HLW glass would decrease by $13 \%$. Due to the uncertainties and limitations surroundiug the sulfate partitioning assumptions currently used for system plannitig and modeling purposes, it would be worthwhile to reexamine both sulfate partitioning and possibly the starting $\mathrm{SO}_{4}$ inventory.

The second most liniting constraint for the $1996 \mathrm{GFM}$ was $\mathrm{A}_{2} \mathrm{O}_{3}$ at 433 batches and $24.0 \%$ of the total glass mass. This constraint almost completely disappears in the $2009 \mathrm{GFM}$ and is replaced with the nepheline discriminator which limits 459 batches and $22.5 \%$ of the tolal glass mass. The nepheline discriminator has the form:

$$
\frac{X_{\mathrm{StO2}}}{X_{\mathrm{At} 2 \mathrm{O3}}+X_{\mathrm{HaO2}}+X_{S t O 2}}
$$

It is expected that the average nepheline value would decrease as the mass fraction of $\mathrm{Al}_{2} \mathrm{O}_{3}$ increases. The $2009 \mathrm{GFM}$ relares the $\mathrm{Al}_{2} \mathrm{O}_{3}$ model validity constraint to $20 \%$ from the $17 \%$ used by the 1996 GFM so the batches that were previously limited by $\mathrm{Al}_{2} \mathrm{O}_{3}$ should be largely limited by nepheline in the new model. This is exactly what is happening in this instance.

Table 8-4 compares, on a batch-by-batch basis, the limiting constraints for the 1996 and 2009 GFM. The columns show the number of batches that are limited by the 1996 constraint shown at the top of the column. The rows show the number of batches that are limited by the 2009 constraint to the left of the row. The intersection of a colunio and a row shows the number of batches that were limited 
by the 1996 constraint that the column belongs to and by the 2009 constraint that the row belongs to. For example, if the arrow is followed from the top of $\mathrm{Cr}_{2} \mathrm{O}_{3}$ down to the 15 and over left to $\mathrm{MnO}$, it shows that 15 batches that were limited by $\mathrm{Cr}_{2} \mathrm{O}_{3}$ in the $1996 \mathrm{GFM}$ are now limited by the $\mathrm{MnO}$ constraint in the 2009 GFM. Similarly, the $\mathrm{Al}_{2} \mathrm{O}_{3}$ column shows that of the 433 batches that were $\mathrm{Al}_{2} \mathrm{O}_{3}$ limited, 380 are now limited by nepheline in the new model.

Table 8-3 2009 GFM Drivers that predict more than a 5\% increase in HLW Mass

\begin{tabular}{|c|c|c|c|}
\hline \multicolumn{3}{|c|}{ Constraints } & \multirow{2}{*}{$\begin{array}{c}\begin{array}{c}\text { Number of } \\
\text { Batches }\end{array} \\
0 \\
\end{array}$} \\
\hline \multirow{19}{*}{$\begin{array}{c}\text { Glass } \\
\text { Composition } \\
\text { Constraints }\end{array}$} & \multirow{6}{*}{ Solubility Limited } & $\mathrm{SO}_{3}$ & \\
\hline & & $\mathrm{F}$ & 38 \\
\hline & & $\mathrm{X}_{\mathrm{CaO}} \cdot \mathrm{X}_{\mathrm{P} 2 \mathrm{O} 5}$ & 31 \\
\hline & & $\mathrm{Li}_{2} \mathrm{O}$ & 0 \\
\hline & & $\mathrm{Cr}_{2} \mathrm{O}_{3}$ & 0 \\
\hline & & Subtotal & 69 \\
\hline & \multirow{13}{*}{ Model Validity Limited } & $\mathrm{Al}_{2} \mathrm{O}_{3}$ & 0 \\
\hline & & $\mathrm{B}_{2} \mathrm{O}_{3}$ & 1 \\
\hline & & $\mathrm{Bi}_{2} \mathrm{O}_{3}$ & 100 \\
\hline & & $\mathrm{CaO}$ & 1 \\
\hline & & $\mathrm{CdO}$ & 0 \\
\hline & & $\mathrm{Fe}_{2} \mathrm{O}_{3}$ & 3 \\
\hline & & $\mathrm{SiO}_{2}$ & 1 \\
\hline & & $\mathrm{MnO}$ & 1 \\
\hline & & $\mathrm{Na}_{2} \mathrm{O}$ & 0 \\
\hline & & $\mathrm{P}_{2} \mathrm{O}_{5}$ & 59 \\
\hline & & $\mathrm{UO}_{3}$ & 27 \\
\hline & & $\mathrm{ZrO}_{2}$ & 0 \\
\hline & & Subtotal & 193 \\
\hline \multirow{5}{*}{$\begin{array}{c}\text { Glass Property } \\
\text { Constraints }\end{array}$} & \multicolumn{2}{|c|}{ Glass Composition Constraints Subtotal } & 262 \\
\hline & \multicolumn{2}{|c|}{$\mathrm{T}_{1 \%-\mathrm{sp}}$ involved } & 2 \\
\hline & \multicolumn{2}{|c|}{ Only TL-zr involved } & 0 \\
\hline & \multicolumn{2}{|c|}{ Only Nepheline } & 1 \\
\hline & \multicolumn{2}{|c|}{ Glass Property Constraints Subtotal } & 3 \\
\hline \multicolumn{3}{|c|}{ Total } & 265 \\
\hline
\end{tabular}


RPP-RPT-42649, REV. 0

Table 8-4 Comparison of Drivers

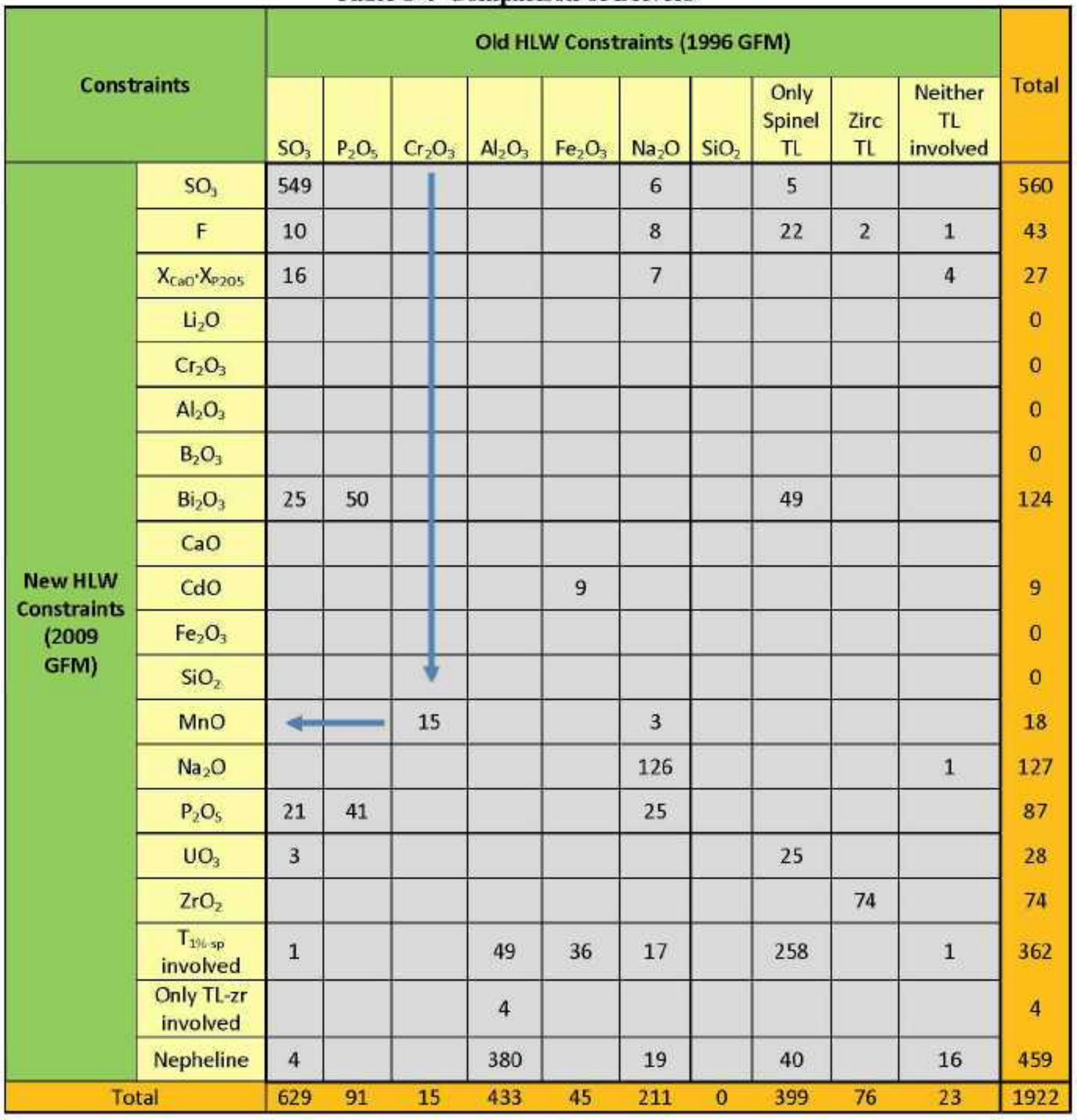


The switch between the $\mathrm{Al}_{2} \mathrm{O}_{3}$ driver and the nepheline driver is the major difference between the 1996 GFM and the 2009 GFM. A few other notable changes are shown by Table 8-4. The zircon liquidus temperature constraint in the 1996 model was almost completely replaced with a zircon model validity constraint in the 2009 model. This change in drivers had minimal effect on the predicted final glass mass. The second notable change is the effect of the $\mathrm{Bi}_{2} \mathrm{O}_{3}$ limit. $\mathrm{Bi}_{2} \mathrm{O}_{3}$ is the glass driver for $7.5 \%$ of the total glass mass in the 2009 GFM and is not present in the $1996 \mathrm{GFM}$. As was discussed above, Table 8-3 shows that the $\mathrm{Bi}_{2} \mathrm{O}_{3}$ constraint generally predicts a lower waste oxide loading than the $1996 \mathrm{GFM}$ does for the same batch. Ont of the 124 batches that are limited by $\mathrm{Bi}_{2} \mathrm{O}_{3}$ in the 2009 GFM. 100 of them predicted a greater than $5 \%$ increase in glass mass than was predicted by older model. This has a small, but noticeable, effect on the predicted glass mass and is one of the primary reasons that, despite the relaxation of the model validity limits, the two models predict nearly identical glass masses.

\subsection{SENSITIVITY STUDY FOR NEW MODEL}

The constraints that were determined to be the most promising candidates for improvement were: $\mathrm{SO}_{3}$, nepheline, $\mathrm{Na}_{2} \mathrm{O}, \mathrm{P}_{2} \mathrm{O}_{5}$ and $\mathrm{Bi}_{2} \mathrm{O}_{3}$. Of these $\mathrm{SO}_{3}$ nepheline, and $\mathrm{Bi}_{2} \mathrm{O}_{3}$ were looked at in a parametric study. $\mathrm{Na}_{2} \mathrm{O}$ and $\mathrm{P}_{2} \mathrm{O}_{5}$ were varied once to determine the effect on the mass of the predicted waste glass. In addition, several constraints were varied together to fith their combined effect on the waste oxide loading. In every case, the predicted glass mass is reported as percentage of the reference case, where the reference case is the total waste glass mass when all batches are calculated using the 2009 GFM constraint values reconmended in PNNL-18501 and reiterated in Table 3-2.

\subsubsection{Nepheline Diseriminator}

The appendix to Glass Property Data and Models for Estmatng High-Level Waste Glass Volume PNNL-18501 suggests that the lower limit for the 10epheline discriminator could be as low as 0.45 . The parametric study looked at the effects of varying nepheline constraint between 0.62 and 0.45 . Optimization runs took place at constraint values of $0.62,0.60,0.57,0.55,0.53,0.51$ and 0.45 .

Table 8-5 displays the results. The right side of the table shows the top five glass drivers along with constraints of interest (shown in bold). Nepheline is no longer a glass driver at a value of 0.45 . At this point the predicted glass mass is $2.6 \%$ percent less than the reference case. While improvements in waste oxide loading are shown down to a nepheline discriminator value of 0.45 , the retnms sharply diminish atter a value of 0.57 . The total mass of the waste glass has a $1 \%$ decrease when the nepheline changes from 0.60 to 0.57 , but only a $0.2 \%$ decrease when the nepheline constraint is dropped from 0.57 to 0.55 . A similar $0.1 \%$ decrease is shown when the constraint is changed from 0.55 to 0.45 .

The connection between $\mathrm{Al}_{2} \mathrm{O}_{3}$ and nepheline was discussed in section 8.1.1. The reverse phenomenon is seen here. As a reminder, the nepheline discriminator is:

$$
\frac{X_{\mathrm{SiO} 2}}{X_{A 203}+X_{\mathrm{Na2O}}+X_{\mathrm{SLO} 2}}
$$


Table 8-5 Nepheline Sensitivity Study

\begin{tabular}{|c|c|c|c|c|c|c|c|c|c|}
\hline \multirow[b]{2}{*}{$\begin{array}{l}\text { Nepheline } \\
\text { Discriminator }\end{array}$} & \multirow[b]{2}{*}{$\begin{array}{l}\text { Total Waste } \\
\text { Glass Mass } \\
\text { (MT) }\end{array}$} & \multirow[b]{2}{*}{$\begin{array}{c}\text { Average } \\
\text { WOL }\end{array}$} & \multirow[b]{2}{*}{$\begin{array}{l}\text { Predicted Mass } \\
\text { as percentage of } \\
\text { reference case }\end{array}$} & \multicolumn{6}{|c|}{ Top Five Drivers - by Final Glass Mass $\%$} \\
\hline & & & & $\mathrm{SO}_{3}$ & Nepheline & $\mathbf{T}_{1 \% \text {-sp }}$ & $\mathrm{ZrO}_{2}$ & $\mathrm{Bi}_{2} \mathrm{O}_{3}$ & $\mathbf{A l}_{2} \mathbf{O}_{3}$ \\
\hline 0.62 & 46,303 & 0.305 & $100.0^{\circ} \%$ & $36 \%$ & $23 \%$ & $14 \%$ & $5 \%$ & $8 \%$ & $0 \%$ \\
\hline 0.60 & 45,686 & 0.310 & $98.7 \%$ & $37 \%$ & $18 \%$ & $15 \%$ & $5 \%$ & $8 \%$ & $2 \%$ \\
\hline 0.57 & 45,244 & 0.313 & $97.7 \%$ & $38 \%$ & $4 \%$ & $13 \%$ & $5 \%$ & $8 \%$ & $17 \%$ \\
\hline 0.55 & 45,151 & 0.313 & $97.5 \%$ & $38 \%$ & 19 Batches & $12 \%$ & $5 \%$ & $8 \%$ & $21 \%$ \\
\hline 0.53 & 45,107 & 0.313 & $97.4 \%$ & $38 \%$ & 2 batches & $12 \%$ & $5 \%$ & $8 \%$ & $22 \%$ \\
\hline 0.51 & 45,096 & 0.314 & $97.4 \%$ & $38 \%$ & 1 batch & $12 \%$ & $5 \%$ & $8 \%$ & $22 \%$ \\
\hline 0.45 & 45,079 & 0.314 & $97.4 \%$ & $38 \%$ & $0 \%$ & $12 \%$ & $5 \%$ & $8 \%$ & $22 \%$ \\
\hline
\end{tabular}


When the acceptable nepheline limit is lowered, the amount of sodium added to the glass can decrease. This causes the mass fraction of $\mathrm{Al}_{2} \mathrm{O}_{3}$ to increase If the nepheline discriminator is lowered enough. $X_{\text {Alzos }}$ will increase and begin to hit its nodel validity limit.

\subsection{2 $\quad \mathrm{Bi}_{2} \mathrm{O}_{3}$}

The goal of this portion of the study was to determine at what point the $\mathrm{Bi}_{2} \mathrm{O}_{3}$ constraint is no longer a glass driver. The model validity limit for $\mathrm{Bi}_{2} \mathrm{O}_{3}$ can be relaxed fron $3.2 \%$ up to $16.37 \%$. This value greatly exceeded the expected concentration of $\mathrm{Bi}_{2} \mathrm{O}_{3}$ in the glass, so a lower value was cliosen for testing. The $\mathrm{Bi}_{2} \mathrm{O}_{3}$ constraint was raised to $10.0 \%$ and the glass resulting from all of the batches were calculated. For the calculated batches, the largest mass percent of $\mathrm{Bi}_{3} \mathrm{O}_{3}$ was $6.61 \%$. Since the amount of $\mathrm{Bi}_{2} \mathrm{O}_{3}$ in the waste glass never exceeds $6.61 \%, 6.7 \%$ was identified as the value at which the $\mathrm{Bi}_{2} \mathrm{O}_{3}$ constraint would no longer linit WOL. Additional runs were performed at $\mathrm{Bi}_{2} \mathrm{O}_{3}$ upper limits of $6.6 \%$ and $6.7 \%$ to verify this result. At $6.6 \%$, one batch was limited by the $\mathrm{Bi}_{2} \mathrm{O}_{3}$ constraint and at $6.7 \%$ no batches were limited by $\mathrm{Bi}_{2} \mathrm{O}_{3}$, thus confirming that $6.7 \%$ was the minimum value at which $\mathrm{Bi}_{2} \mathrm{O}_{3}$ was not an active constraint.

The impact of $\mathrm{Bi}_{2} \mathrm{O}_{3}$ on the predicted waste glass mass was not as great as that of the nepheline discriminator. Relaxing the constraint from $3.2 \%$ to $6.7 \%$ only led to a $1.5 \%$ improvement in waste glass mass. The right side of Table $8-6$ shows that the batches formerly limited by $\mathrm{Bi}_{2} \mathrm{O}_{3}$ were transferred fairly equally to the remaining constraints. As one constraint is relaxed, other constraints often become limiting with little improvement in waste loading.

\section{$8.2 .3 \quad \mathrm{SO}_{3}$}

Of the constraints studied. $\mathrm{SO}_{3}$ has, by far, the largest impact. The effect of varying the $\mathrm{SO}_{3}$ constraint was tested at $0.5 \%, 0.6 \%, 0.7 \%, 0.8 \%, 0.9 \%$ and $1.0 \%$. At the most relaxed value $(1.0 \%)$ the predicted glass mass was reduced by $14.4 \%$. The slightly relaxed value of $0.6 \%$ even shows a significant reduction in predicted glass mass, at $5.7 \%$. Even at $1.0 \%$ solubility, $\mathrm{SO}_{3}$ remained in the top five glass drivers, limiting the waste oxide loading for $7.9 \%$ of the glass. If the solubility limit could be increased past $1.0 \%$ it would continue to yield positive results.

Once again the top five glass drivers are shown on the right half of Table 8-7. As $\mathrm{SO}_{3}$ drops from being the liniting constraint for over $1 / 3$ of the waste glass to being the liniting constraint for $8 \%$ of the waste glass mass, the percent of the glass linited by both nepheline and $\mathrm{Bi}_{2} \mathrm{O} 3$ increases. This strongly suggest that lowering the $\mathrm{SO}_{3}$, nepheline, and $\mathrm{Bi}_{2} \mathrm{O}_{3}$ onstraints at the sane time would have an effect that is greater than the sum of telaxing each constraint individually.

\subsection{4 $\mathrm{Na}_{2} \mathrm{O}$ and $\mathrm{P}_{2} \mathrm{O}_{5}$}

Unlike the previous three constraints, both $\mathrm{Na} 2 \mathrm{O}$ and $\mathrm{P}_{2} \mathrm{O}_{5}$ were only varied once. $\mathrm{Na}_{2} \mathrm{O}$ was relaxed to $23.0 \%$ from $21.4 \%$ as suggested by VSL-06R6480-3. The $\mathrm{P}_{2} \mathrm{O}_{5}$ constraint was relaxed to the solubility limit of $4.5 \%$. The results are shown in the first two lines of Table 8-8. The effects are minimal. Relaxing the $\mathrm{Na}_{2} \mathrm{O}$ constraint resulted in a reduction of $0.5 \%$ of predicted waste glass mass. The relaxed $\mathrm{P}_{2} \mathrm{O}_{5}$ constraint reduced the glass mass by $0.4 \%$. These are small improvements, but 
RPP-RPT-42649, REV, 0

relaxing either of these constraints in conjunction with other constraints will show improvements tha1 are greater than the sum of relaxing each individual constraint. 
Table 8-6 $\mathrm{Bi}_{2} \mathrm{O}_{3}$ Sensitivity Study

\begin{tabular}{|c|c|c|c|c|c|c|c|c|c|}
\hline \multirow[b]{2}{*}{$\begin{array}{c}\mathrm{Bi}_{2} \mathrm{O}_{3} \text { Model } \\
\text { Validity Limit }\end{array}$} & \multirow[b]{2}{*}{$\begin{array}{l}\text { Total Waste } \\
\text { Glass Mass } \\
\text { (MT) }\end{array}$} & \multirow[b]{2}{*}{$\begin{array}{c}\text { Average } \\
\text { WOL }\end{array}$} & 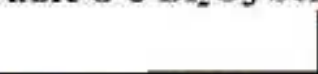 & \multicolumn{6}{|c|}{ Top Five Drivers - by Final Glass Mass $\%$} \\
\hline & & & $\begin{array}{c}\text { Predicted Mass } \\
\text { as percentage } \\
\text { of reference } \\
\text { case }\end{array}$ & $\mathrm{SO}_{3}$ & Nepheline & $\mathbf{T}_{1 \%-\mathrm{sp}}$ & $\mathrm{Na}_{2} \mathrm{O}$ & $\mathrm{Bi}_{2} \mathrm{O}_{3}$ & $\mathrm{P}_{2} \mathrm{O}_{5}$ \\
\hline $3.2 \%$ & 46,303 & 0.305 & $100.0 \%$ & $36 \%$ & $23 \%$ & $14 \%$ & $5 \%$ & $8 \%$ & $4 \%$ \\
\hline $4.2 \%$ & 45,734 & 0.309 & $98.8 \%$ & $38 \%$ & $23 \%$ & $14 \%$ & $5 \%$ & $2 \%$ & $6 \%$ \\
\hline $6.6 \%$ & 45,592 & 0.310 & $98.5 \%$ & $38 \%$ & $23 \%$ & $14 \%$ & $5 \%$ & $\begin{array}{c}1 \\
\text { batch }\end{array}$ & $8 \%$ \\
\hline $6.7 \%$ & 45,592 & 0.310 & $98.5 \%$ & $38 \%$ & $23 \%$ & $14 \%$ & $5 \%$ & $0 \%$ & $8 \%$ \\
\hline $10.0 \%$ & 45,592 & 0.310 & $98.5 \%$ & $38 \%$ & $23 \%$ & $14 \%$ & $5 \%$ & $0 \%$ & $8 \%$ \\
\hline
\end{tabular}


Table 8-7 $\mathrm{SO}_{3}$ Sensitivity Study

\begin{tabular}{|c|c|c|c|c|c|c|c|c|}
\hline \multirow[b]{2}{*}{$\begin{array}{c}\mathrm{SO}_{3} \\
\text { Solubility } \\
\text { Limit }\end{array}$} & \multirow[b]{2}{*}{$\begin{array}{c}\text { Total Waste } \\
\text { Glass Mass } \\
\text { (MT) }\end{array}$} & \multirow[b]{2}{*}{$\begin{array}{c}\text { Average } \\
\text { WOL }\end{array}$} & \multirow[b]{2}{*}{$\begin{array}{l}\text { Predicted mass as } \\
\text { percentage of } \\
\text { reference case }\end{array}$} & \multicolumn{5}{|c|}{ Top Five Drivers - by Final Glass Mass $\%$} \\
\hline & & & & $\mathrm{SO}_{3}$ & Nepheline & $\mathbf{T}_{1 \% \text { sp }}$ & $\mathrm{NaO}_{2}$ & $\mathrm{Bi}_{2} \mathbf{O}_{3}$ \\
\hline $0.5 \%$ & 46,303 & 0.305 & $100.0 \%$ & $36 \%$ & $23 \%$ & $14 \%$ & $5 \%$ & $8 \%$ \\
\hline $0.6 \%$ & 43,641 & 0.324 & $94.3 \%$ & $29 \%$ & $25 \%$ & $14 \%$ & $6 \%$ & $9 \%$ \\
\hline $0.7 \%$ & 41,920 & 0.337 & $90.5 \%$ & $23 \%$ & $28 \%$ & $15 \%$ & $6 \%$ & $10 \%$ \\
\hline $0.8 \%$ & 40,788 & 0.347 & $88.1 \%$ & $18 \%$ & $31 \%$ & $15 \%$ & $6 \%$ & $11 \%$ \\
\hline
\end{tabular}


Table 8-8 Relaxing Multiple Constraints

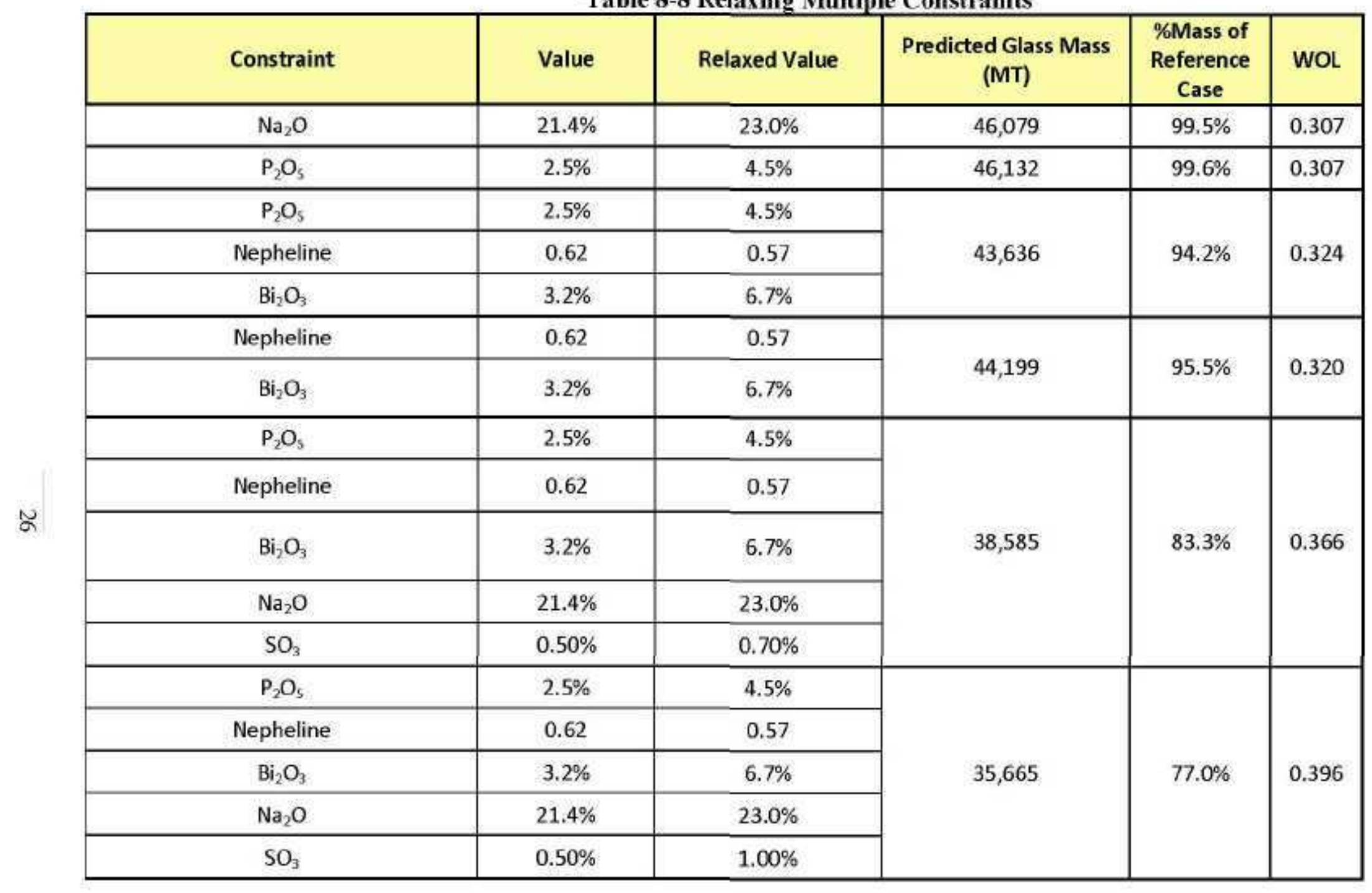




\subsubsection{Relaxing Multiple Constraints}

In the previous sections, the change in glass drivers as a single constraint was lowered implied that lowering nultiple constraints jointly would have a synergistic effect. That is what is displayed in ruos 3-6 on Table 8-8. Raising the $\mathrm{P}_{2} \mathrm{O}_{5}$ constraint to $4.5 \%$ only results io a $0.4 \%$ reduction in predicted waste glass mass. However, raising the $\mathrm{P}_{2} \mathrm{O}_{5}$ constraint to $4.5 \%$ in conjunction with relaxing the nepheline and $\mathrm{Bi}_{2} \mathrm{O}_{3}$ constraint has a larger impact on predicted glass mass. The predicted decrease in glass mass, if each constrain was relaxed separately is $4.5 \%$. When all three constraints are relaxed simultaneously, the glass mass decreases by $5.8 \%$. This is slown in nuns 3 and 4 of Table $8-8$.

Runs 5 and 6 give an idea of the benefit of relaxing all of the selected constraints jointly. Run 6 shows what oceurs if nepheline is lowered to 0.57 and all the other constraints are relaxed to the maximum values used in this study. The predicted waste glass mass in this run was $23.0 \%$ lower than the reference case. Run 5 uses the same constraint values that run 6 does, but the $\mathrm{SO}_{3}$ constraint is relaxed to $0.7 \%$ instead of $1.0 \%$. In this case the predicted waste glass mass is $16.7 \%$ less than the reference case. Additional glass formulation work would be needed to support relaxing these constraints and it is likely that as multiple constraints are relased, other constraints will become more prominent drivers and the incremental improvements in waste oxide loading may diminish.

\subsection{CONCLUSIONS}

Despite relaxed model validity constraints, the 2009 GFM model predicts very sinular waste oxide loading and HLW glass mass as the 1996 model does. This can be attributed to two solubility limits. $\mathrm{F}$ - and $\mathrm{X}_{\mathrm{CaO}_{0}} \times \mathrm{Xpos}_{\mathrm{p}}$, and two model validity limits, $\mathrm{Bi}_{2} \mathrm{O}_{3}$ and $\mathrm{UO}_{3}$, that were not present in the older nodel.

In order of decreasiog importance, the top five glass drivers for each model are:

- 2009 GFM: $\mathrm{SO}_{3}$, nepheline discriminator, $\mathrm{T}_{1 \%}-\mathrm{Sp}, \mathrm{Bi}_{2} \mathrm{O}_{3}, \mathrm{Na}_{2} \mathrm{O}$

- 1996 GFM: $\mathrm{SO}_{3}, \mathrm{Al}_{2} \mathrm{O}_{3}, \mathrm{~T}_{\mathrm{L}}-\mathrm{sp}, \mathrm{Na}_{2} \mathrm{O}_{4} \mathrm{~T}_{2}$-zircon

$\mathrm{SO}_{3}$ contioned to be the primary glass driver, $\mathrm{Al}_{2} \mathrm{O}_{3}$ was second largest glass driver in the 1996 GFM with it linitiong $24.0 \%$ of the lotal waste glass mass. The $2009 \mathrm{GFM}$ relaxed the $\mathrm{Al}_{2} \mathrm{O}_{3}$ model validity constraint to $20 \%$ from $17 \%$. As a result, the percentage of waste glass mass that was limited by $\mathrm{Al}_{2} \mathrm{O}_{3}$ plummeted to only 2 batches. Other less significant, but still noticeable, differences include an increased number of glass drivers in the 2009 GFM and the appearance of the $\mathrm{Bi}_{2} \mathrm{O}_{3}$ model validity constraint as a major driver.

Within the $2009 \mathrm{GFM}$ the $\mathrm{Na}_{2} \mathrm{O}, \mathrm{P}_{2} \mathrm{O}_{4}, \mathrm{Bi}_{2} \mathrm{O}_{3}, \mathrm{SO}_{3}$ and the nepheline discriminator were identified as the constraints that were most likely to be relaxed, assuming additional glass formulation work, and to have an effect on the predicted waste oxide loading. Of these constraints $\mathrm{SO}_{3}$ had, by far, the largest impact on the predicted waste oxide loading. The most optimistic scenario relaxed the $\mathrm{SO}_{3}$ constraint from $0.5 \%$ to $1.0 \%$. This resulted in a $14.4 \%$ decrease in the predicted wasle glass mass. Even a more conservative. and perhaps more realistic, relaxation of the $\mathrm{SO}_{3}$ constraint to $0.7 \%$ showed a $9.5 \%$ decrease in predicted glass mass. It is important to note that $\mathrm{SO}_{3}$ 's role as the 
primary glass driver is heavily dependent on the sulfate partitioning assumptions in HTWOS. Those assumptions have a significant amount of uncertainty associated with them, and any changes made to decrease or increase the anount of $\mathrm{SO}_{3}$ that ends up in HLW glass may have dramatic effects on both waste oxide loading and the final mass of glass. For example, $\mathrm{SO}_{3}$ no longer plays a role as a glass driver when the amount of sulfate reporting to HLW is cut in balf. The waste oxide loading increases to $36 \%$ and the total mass of glass decreases by $13 \%$ in that ase. Despile these improvements, other constraints become more prominent glass drivers as $\mathrm{SO}_{3}$ 's role is diminished. particularly nepheline, $\mathrm{Bi}_{2} \mathrm{O}_{3}$. F- and $\mathrm{P}_{2} \mathrm{O}_{5}$.

The effect of relaxing the second nost limiting constraint, the tephelite discriminator, is less impressive. Nepheline is no longer a glass driver at a value of 0.45 . This results in a $2.6 \%$ improvemen1 in predicted waste glass mass. The effect of reducing the nepheline discriminator lower limit begins to show significant diminishing retums after 0.57 . At this point the predicted waste glass mass shows a $2.3 \%$ improvement from the reference case.

The other constraints show an even smaller effect when relaxed. $\mathrm{Bi}_{2} \mathrm{O}_{3}$ does not limit the waste oxide loading on any batches once the model validity limit is raised to $6.7 \%$. The predicted waste glass nass is $1.5 \%$ less than the reference case when this oceurs. When $\mathrm{Na}_{2} \mathrm{O}$ and $\mathrm{P}_{2} \mathrm{O}_{5}$ are relaxed to $23.0 \%$ and $4.5 \%$, respectively, both show less than a $1 \%$ decrease in predicted waste glass mass.

When inultiple constraints are relaxed together, the effect is greater than the sum of relaxing each constraint individually. Relaxing nepheline to 0.57 and the rest of the constraints to their maximum values results in a $23.0 \%$ reduction in predicted wasle glass mass. If the above scenario is repeated except with the $\mathrm{SO}_{3}$ constraint relaxed to $0.7 \%$, the predicted waste oxide mass is $16.7 \%$ less than the reference case.

\subsection{RECOMMENDATIONS}

PNNL-18501 shows that there is a relatively high level of uncertainty around the $\mathrm{SO}_{3}$ constraint. Evidence suggests that this limit could go as high as $1.0 \%$. Given the large impact that relaxing the $\mathrm{SO}_{3}$ constraint has on the predicted waste oxide loading, it is recommended that more work be done to pinpoint the concentration of $\mathrm{SO}_{3}$ that the melter can handle.

The mass balance for the SP4 initial planning case. SVF-1663, shows $1.7 \%$ of the $\mathrm{SO}_{4}$ going to the HLW melters as part of the pretreated feed. As the Revew of Phosphate and Sulfate Wash and Leach Factors. RPP-25903, suggests, there is a fairly high level of uncertainty surrounding the assumptions utiderlying the sulfate partitioning. Since $\mathrm{SO}_{3}$ (which is the product of the sulfate decomposition reaction in the melter) has a large impact on the predicted waste oxide loading in both the 1996 and 2009 GFM. it may be prudent to revisit sulfate partitioning assumptions. HLW glass contains only $1.7 \%$ of the $\mathrm{SO}_{4}$ and it becomes the limiting constraint for nearly $40 \%$ of the wasie glass mass. Small inaccuracies in the partitioning assumptions could, therefore, led to predictions that widely over or under predict the amount of HLW glass produced.

The nepheline discriminator has a lesser impact on predicted waste glass mass, but lowering it to 0.45 does decrease the predicted waste glass mass by $2.6 \%$. Reducing it to the more conservative 
value of 0.57 has a similar effect - a $2.3 \%$ reduction in predicted glass mass. There would be value in investigating whether the nepheline constraint can be lowered.

$\mathrm{Bi}_{2} \mathrm{O}_{3}, \mathrm{Na}_{2} \mathrm{O}$ and $\mathrm{P}_{2} \mathrm{O}_{5}$ have even smaller effects on the predicted waste oxide loading. There probably is not a large incentive in lowering any of these constraints independently, but since lowering multiple constraints together has a greater impact than the sum of relaxing each constraint alone, it would be worth studying whether the $\mathrm{Bi}_{2} \mathrm{O}_{3}, \mathrm{Na}_{2} \mathrm{O}$, or $\mathrm{P}_{2} \mathrm{O}_{5}$ constraints could be relaxed.

The effect of varying the $T_{1 \%}$ - Spinel constraint was not investigated in this study, but since it limits $13.5 \%$ of the total waste glass mass, any work done making the constraint less restrictive could yield beneficial improvements in predicted waste oxide loading.

\subsection{REFERENCES}

PNNL-10987 Effect of Composition and Temperature on the Properties of High-Level Waste (HLW) Glas: Melting Above $1200^{\circ} \mathrm{C}$ (DRAFT). Vienna. JD et of. Pacific Northwest National Laboratory, Richland, Washington.

PNNL-1 1790 Liqudus Temperature Data for DWPF Glass. Hrma, P, JD Vienna, M. Mika, JV Crum. GF Piepel. Pacific Northwest National Laboratory, Richland, Washington.

PNNL-18501 Gkass Property Data and Models for Estmatmg High-Level Waste Glass VoluneDroft 6-9-09. Vienua, JD, A Fluegel, DS Kin, P Hrma. Pacific Northwest National Laboratory. Richland, Washington.

RPP-25903, Rev. 0 Revew of Phosphate and Stlfate Wash and Leach Factors. Orme. Rou. CH2MHill: Hauford Group, Inc, Ricluand, Washington.

SVF-1663. Rev 0, WTP_HLW_Glass_SP4 Planning Case-3.0-8.470-2009-03-30-at-20-0139 MII.wLs. Washington River Protection Solutions, Richland, Washington.

SVF-1748. Rev, 2, High-Level Waste GFM. Washington River Protection Solutions, Richland Washingion.

SVF-1766, Rev, 0, 2009 GFM Sensitrvty Study. Washington River Protection Solutions, Richland Washinglon.

Vienna, John. Personal Communication. 31 July. 2009

VSL-06R6480-3 Preparation and Testing of LAW High-Alkal Correlation and Augmentation Montm Glasses. Vitreous State Laboratory, Muller IS, I Joseph, and IL Pegg. The Catholic University of America, Washington, D.C.

WHC-SD-WM-TI-768, Rev. 0 Tank Waste Remedratron System Phase I High-Level Waste Feed Procestabilty Assessment Report. Lambert, SL, GE Stegan. Westinghouse Hanford Company Riclland, WA; Vienua, JD. Pacific Northwest National Laboratory, Riclland Waslington. 